\title{
Fiscal Year 1996 Laboratory Scale Studies of Cesium Elution in Tank 8D-1
}
R. L. Russell
G. K. Patello
J. A. Sills

September 1996

Prepared for the U.S. Department of Energy under Contract DE-AC06-76RLO 1830

Pacific Northwest National Laboratory

Operated for the U.S. Department of Energy. by Battelle 


\title{
DISCLAIMER
}

This report was prepared as an account of work sponsored by an agency of the United States Government. Neither the United States Government nor any agency thereof, nor Battelle Memorial Institute, nor any of their employees, makes any warranty, express or implied, or assumes any legal liability or responsibility for the accuracy, completeness, or usefulness of any information, apparatus, product, or process disclosed, or represents that its use would not infringe privately owned rights. Reference herein to any specific commercial product, process, or senvice by trade name, trademark, manufacturer, or otherwise does not necessarily constitute or imply its endorsement, recommendation, or favoring by the United States Government or any agency thereof or Battelle Memorial Institute. The views and opinions of authors expressed herein do not necessarily state or reflect those of the United States Government or any agency thereof.

\author{
PACIFIC NORTHWEST NATIONAL LABORATORY \\ operated by \\ BATTELLE \\ for the \\ UNITED STATES DEPARTMENT OF ENERGY \\ under Contract DE-AC06-76RLO 1830
}

Printed in the United States of America

Available to DOE and DOE contractors from the

Office of Scientific and Technical Information, P.O. Box 62, Oak Ridge, IN 37831; prices available from (615) $576-8401$.

Available to the public from the National Tectnical Information Service,

U.S. Department of Commerce, 5285 Port Royal Rd., Springfield, VA 22161

The document was printed on recycled paper, 
Fiscal Year 1996 Laboratory Scale Studies of Cesium Elution in Tank 8D-1

\author{
R. L. Russell \\ G. K. Patello \\ J. A. Sills
}

September 1996

Prepared for

the U.S. Department of Energy

under Contract DE-AC06-76RLO 1830

Pacific Northwest National Laboratory

Richland, Washington 99352 


\section{DISCLAIMER}

Portions of this document may be illegible in electronic image products. Images are produced from the best available original document. 



\section{QA Level}

This work was performed to satisfy WVSP FY 1996 milestone number 0604A and was conducted in accordance with Impact Level II quality assurance requirements as defined by the WVSP Quality Assurance Plan ETD-007 and the PNNL Quality Assurance Manual PNNL-MA-70. 



\section{Summary}

During the vitrification phase of the West Valley Demonstration Project (WVDP) waste remediation, an estimated $95 \%$ of the zeolite in tank 8D-1 will be transferred to tank 8D-2, leaving behind residual cesium-loaded zeolite, which will require treatment to remove the cesium.

Oxalic acid has been proposed as a reagent for the elution of cesium from zeolite in tank 8D-1. During FY 1995, nonradioactive laboratory-scale tests were performed to determine optimum conditions for cesium elution in terms of acid-to-zeolite ratio, contact time, and temperature of acid addition, and to evaluate the effects of multiple contacts, long-term contacts, presence of corrosion products, lack of agitation, temperature of tank contents, and oxalic acid concentration. During FY 1996, follow-up studies included examining the effects of reduced amounts of corrosion products $\left(\mathrm{Fe}_{2} \mathrm{O}_{3}\right)$, the presence of nitrate and nitrite salts, smaller particle size zeolite, and neutralization by $\mathrm{NaOH}$ on cesium elution.

Although the amounts of cesium eluted after 28 hours were essentially the same in all four tests with different amounts of iron, adding larger amounts of $\mathrm{Fe}_{2} \mathrm{O}_{3}$ tended to slow the overall cesium elution process at the shorter contact times ( $<20$ hours). Furthermore, $34-39 w t \%$ of the iron added to the system had dissolved after 28 hours of contact, regardless of the absolute amount of $\mathrm{Fe}_{2} \mathrm{O}_{3}$ present.

Within the bounds of experimental error $( \pm 10 \%)$, the presence of nitrate and nitrite salts appears to have no effect on cesium elution. However, at 20 and 28 hours contact, the amount of dissolved iron was significantly lower in the presence of salts than in the control ( $21 \mathrm{wt} \%$ vs. $34 \mathrm{wt} \%$ ).

Cesium elution levels in the test with the smaller zeolite particles were higher than the control at short contact times; however, after 20 hours of contact, the amounts of cesium eluted in the test and the control were within experimental error.

Neutralizing with $\mathrm{NaOH}$ after 20 hours to $\mathrm{pH} 5$ or 12 made little difference in the amount of cesium eluted. However, iron precipitated when the solution was neutralized to $\mathrm{pH} 12$.

Comparison of percentages of aluminum and cesium in solution showed the same trend for each test indicating that there is a correlation between zeolite dissolution and cesium release.

FY 1995 and FY 1996 studies showed that oxalic acid is an effective agent for eluting cesium from zeolite. An extraction efficiency of $\sim 85 \mathrm{wt} \%$ in a single contact was achieved. In addition, acid neutralization after cesium elution can limit corrosion of the tank and dissolution of accumulated corrosion products. However, acid neutralization will add additional sodium to the melter feed which may create a concern for West Valley. 



\section{Acronyms}

DOE Department of Energy

EPA Environmental Protection Agency

FY

Fiscal Year

HLW

High Level Waste

ICP-MS Inductively Coupled Plasma Mass Spectroscopy

PNNL Pacific Northwest National Laboratory

PUREX Plutonium and Uranium Extraction

QA Quality Assurance

STS Supernatant Treatment System

THOREX Thorium Extraction Process

WVDP West Valley Demonstration Project

WVNS West Valley Nuclear Services

WVSP West Valley Support Project

XRD X-Ray Diffraction

XRF X-Ray Fluorescence 


\section{Contents}

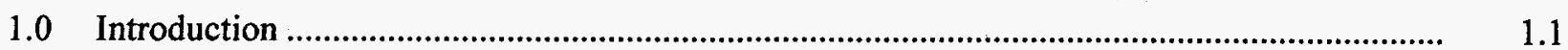

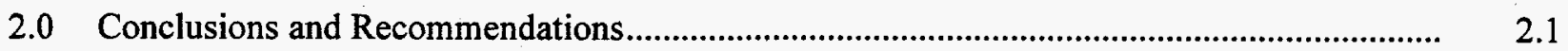

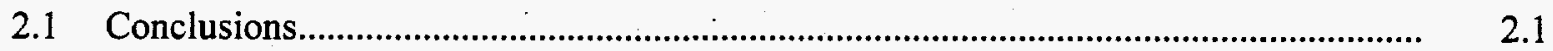

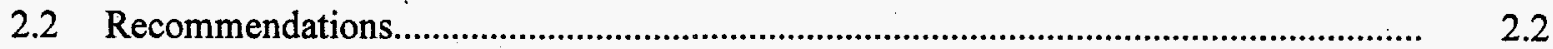

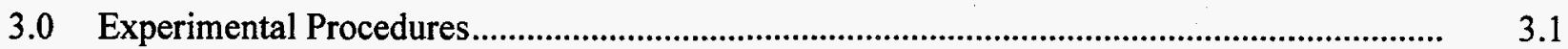

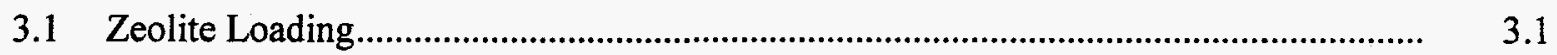

3.2 Cesium Elution Experiments: General Procedure .....................................................

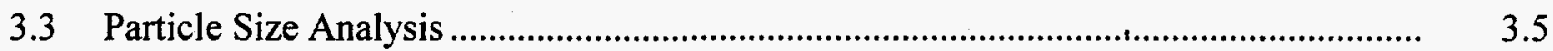

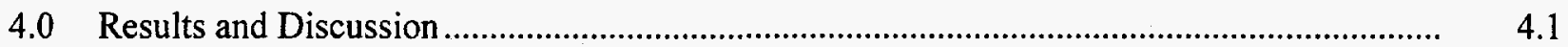

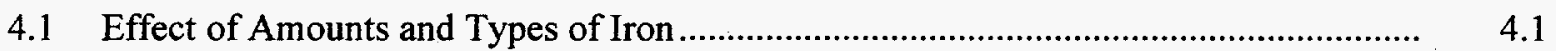

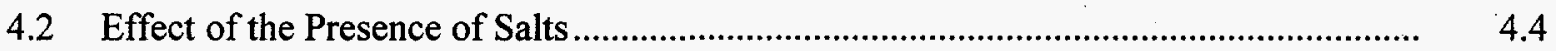

4.3 Effect of Reduced Particle Size Zeolite..................................................................

4.4 Particle Size Analysis of the Zeolite ............................................................................

4.5 Zeolite Loaded to a Higher Level of Cesium .........................................................

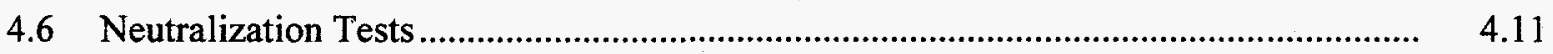

4.7 Relationship Between Cesium Eluted and Aluminum in Solution .............................. 4.14

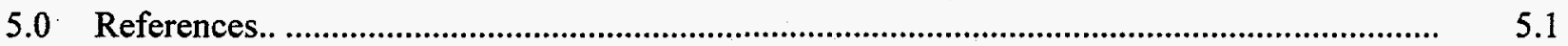

Appendix A -- Contact Conditions......................................................................................... A. A

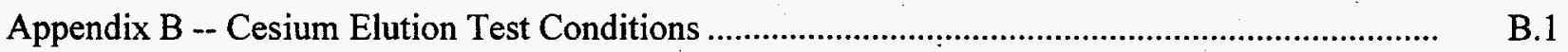

Appendix C -- Temperature and pH Data for Cesium Elution Tests........................................... C.1

Appendix D -- Sample Calculations and Formulas Used in Determination of Percent Cesium Eluted in Cesium Elution Experiments ..................................................... D $\quad$ D.1

Appendix E -- Data: Cesium: Aluminum.............................................................................. E.1 


\section{Figures}

3.1 Reaction Vessel Assembly Used in Cesium Elution Tests

4.1 Percent Cesium Eluted in Tests Containing Various Amounts of $\mathrm{Fe}_{2} \mathrm{O}_{3}(100 \%=$ Total Amount of Cesium Loaded onto Zeolite).

4.2 Percent Iron Dissolved in Tests Containing Iron in Various Forms and Amounts $(100 \%=$ Total Amount of Iron in the System $)$

4.3 Concentrations of Iron in Solution $(\mu \mathrm{g} / \mathrm{g})$ in Tests Containing Iron in Various Amounts and Forms

4.4 Weight Percent Cesium Eluted in Tests 30 and 32 to Determine the Effect of $\mathrm{NaNO}_{2}$ and $\mathrm{NaNO}_{3}$ Salts on Cesium Elution

4.5 Percentage of Iron Dissolved in Tests 30 and 32 to Determine the Effects of $\mathrm{NaNO}_{2}$ and $\mathrm{NaNO}_{3}$ Salts on Cesium Elution

4.6 Weight Percent Cesium Eluted in Test Containing Reduced Particle Size Zeolite

4.7 Effect of Reduced Particle Size Zeolite on Iron Dissolution During Cesium Elution Tests

4.8 Zeolite Particle Size Before Acid Dissolution

4.9 Zeolite Particle Size After Acid Dissolution

4.10 Weight Percent Cesium Eluted in Test to Determine the Effect of Using HigherCesium-Loaded Zeolite on Cesium Elution

4.11 Weight Percent Iron Dissolved in Tests to Determine the Effect of Using Higher Cesium-Loaded Zeolite in Cesium Elution Tests

4.12 Weight Percent Cesium Eluted in Neutralization Tests.

4.13 Weight Percent Iron Dissolved in Neutralization Tests.

4.14 Moles of Aluminum/Moles of Cesium vs. Contact Time for Various Cesium Elution Tests

4.15 Moles of Cesium vs. Moles of Aluminum for Various Cesium Elution Tests.

E.1 Percentage of Aluminum Dissolved in Tests Containing Various Amounts of Iron

E.1 
E.2 Concentration of Aluminum in Solution, in $\mu \mathrm{g} / \mathrm{g}$

E.3 Weight Percent Cesium Eluted and Aluminum Dissolved in Tests to Determine Effect of Added Salts on Cesium Elution

E.4 Weight Percent Cesium Eluted and Aluminum Dissolved in Tests to Determine Effect of Reduced Particle Size Zeolite on Cesium Elution

E.5 Weight Percent Cesium Eluted and Aluminum Dissolved in Tests to Determine Effect of Using Higher-Loaded Zeolite on Cesium Elution

E.6 Weight Percent Aluminum Dissolved and Percent Cesium Eluted in Neutralization Tests 


\section{Tables}

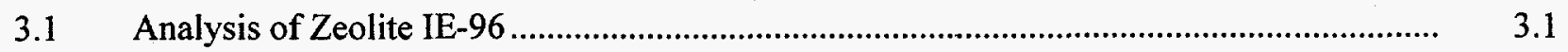

3.2 X-Ray Fluorescence Results for Cesium-Loaded Zeolite..............................................

3.3 Test Matrix for FY96 Cesium Elution Tests.....................................................................

4.1 Weight Percent Cesium Eluted in Tests to Determine Effects of Iron on

Cesium Elution ............................................................................................................... 4.1

4.2 Percent Iron Dissolved in Tests Containing Iron in Various Amounts and Forms .............. 4.2

4.3 Concentrations of Iron in Solution $(\mu \mathrm{g} / \mathrm{g})$ in Tests Containing Iron in Various Forms ....... 4.4

4.4 Weight Percent Cesium Eluted in Tests 30 and 32 to Determine the Effect of Salts on Cesium Elution ...............................................................................................................

4.5 Percentage of Iron Dissolved in Tests 30 and 32 to Determine the Effects of Salts

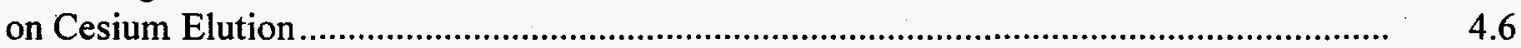

4.6 Weight Percent Cesium Eluted in Test Containing Reduced Particle Size Zeolite.............. $\quad 4.7$

4.7 Effect of Reduced Particle Size Zeolite on Iron Dissolution During Cesium

Elution Tests.

4.8 Weight Percent Cesium Eluted in Test to Determine the Effect of Using Higher-

Cesium-Loaded Zeolite on Cesium Elution.

4.9 Weight Percent Iron Dissolved in Tests to Determine the Effect of Using Higher Cesium-Loaded Zeolite in Cesium Elution Tests

4.10 Weight Percent Cesium Eluted in Neutralization Tests

4.11 Weight Percent Iron Dissolved in Neutralization Tests

4.12 X-ray Diffraction Analysis of Precipitates in Neutralization Tests and Control.

A.1 Conditions for Cesium-Loading of Zeolite

B.1 Test Matrix Used for Cesium Elution Tests $30-40$

C.1 Temperature and pH Data for Cesium Elution Tests $30-34$ and 36-39

C.2 Temperature and pH Data for Cesium Elution Tests 35 and 40.

C.1 
D.1 Sample Calculations and Formulas Used in Determination of Percent Cesium Eluted in Cesium Elution Tests 30 - 40

E.1 Weight Percent Cesium Eluted and Aluminum Dissolved in Experiments to Determine the Effect of the Type and Amount of Iron Present on Cesium Elution

E.2 Concentration of Aluminum in Solution in $\mu \mathrm{g} / \mathrm{g}$

E.3 Weight Percent Cesium Eluted and Aluminum Dissolved in Tests to Determine Effect of Added Salts on Cesium Elution

E.4 Weight Percent Cesium Eluted and Aluminum Dissolved in Tests to Determine Effect of Reduced Particle Size Zeolite on Cesium Elution

E.5 Weight Percent Cesium Eluted and Aluminum Dissolved in Tests to Determine Effect of Using Higher-Loaded Zeolite on Cesium Elution

E.6 Weight Percent Aluminum Dissolved in Neutralization Tests

E.7(a) Test 30: Data Used in Figure 4.13, Plotting Moles Al/Moles Cs

E.7(b) - Test 31: Data Used in Figure 4.13, Plotting Moles Al/Moles Cs

E.7(c) Test 32: Data Used in Figure 4.13, Plotting Moles Al/Moles Cs

E.7(d) Test 36: Data Used in Figure 4.13, Plotting Moles Al/Moles Cs

E.7(e) Test 37: Data Used in Figure 4.13, Plotting Moles Al/Moles Cs

E.8

E.7(f) Test 39: Data Used in Figure 4.13, Plotting Moles Al/Moles Cs

E.8

E.8 Data Used in Figure 4.14, Plotting Moles Al versus Moles Cs

E.9 


\subsection{Introduction}

This report details work performed as part of West Valley Support Project (WVSP) Fiscal Year 1996 Subtask 0604, conducted by the Pacific Northwest National Laboratory (PNNL). This work is intended to support residual waste removal during high-level waste (HLW) tank stabilization activities to be performed by the West Valley Demonstration Project (WVDP). The HLW, approximately 2 million liters, originated from a now inactive commercial nuclear fuel-reprocessing plant at West Valley, New York. It is stored in a carbon-steel tank designated 8D-2. Cesium-loaded zeolite was generated by a supernatant decontamination process involving ion exchange. The exchange columns and the spent zeolite are stored in a carbon-steel tank designated 8D-1 (Cadoff 1991). During the vitrification phase of the WVDP waste remediation, an estimated $95 \mathrm{wt} \%$ of the zeolite will be transferred from tank $8 \mathrm{D}-1$ to tank $8 \mathrm{D}-2$. The remaining cesium-loaded zeolite will require treatment to remove the highly radioactive cesium ${ }^{(a)}$.

Oxalic acid has been studied as a decontamination reagent for nuclear reactors and equipment (Meservey 1970). In laboratory studies ${ }^{(b)}$ oxalic acid [0.8M (7 wt $\left.\%\right)$ oxalic acid at $\sim 20 \mathrm{~L}$ acid/kg zeolite] eluted cesium from zeolite at a level of $88-90 \%$ over 11 days (264 hours).

During FY 1995, studies performed on the use of oxalic acid to elute cesium from zeolite showed that; although no one set of conditions tested could be described as "optimum", $40 \mathrm{~L}$ of $8 \mathrm{wt} \%$ oxalic $\mathrm{acid} / \mathrm{kg}$ zeolite at $50^{\circ} \mathrm{C}$ in a series of three contacts eluted $99 \mathrm{wt} \%$ of the cesium. Most of the cesium elution occurred during the first few hours of contact with oxalic acid; longer times did not significantly increase elution. Addition of $\mathrm{Fe}_{2} \mathrm{O}_{3}$ to the cesium elution tests to simulate corrosion products present on the bottom of tank 8D-1 did not significantly affect cesium elution. However, $\sim 90 \mathrm{wt} \%$ of the iron added to the system dissolved; therefore, as shown in FY 1995, the rust in the tank may be soluble in $8 \mathrm{wt} \%$ oxalic acid. Iron oxide dissolution in tank 8D-1 would cause more iron to enter the vitrification process and may increase the number of glass logs generated. Use of lower concentrations of oxalic acid (4 and $1 \mathrm{wt} \%$ ) decreased iron solubilization to $15-20 \mathrm{wt} \%$ of the iron in the system, but cesium elution efficiency also dropped to $\sim 75 \mathrm{wt} \%$ with three contacts.

This report summarizes the findings of laboratory experiments conducted at PNNL during FY 1996. The primary objectives of the FY 1996 experiments were as follows:

- to further refine the optimum process conditions identified during the FY 1995 work for the use of oxalic acid to elute cesium from zeolite in tank 8D-1; target value, 99 wt \% cesium eluted,

- to minimize iron dissolution during cesium elution,

- to investigate the effect of neutralization on cesium elution,

(a) Schiffhauer, MA. 1994. "Review of Zeolite Transfer Operation and Estimated Duration," Internal West Valley Demonstration Project Memo dated March 24, 1994. West Valley Demonstration Project, West Valley, NY.

(b) Bray, LA. 1986. "Washed Sludge and Cesium/Zeolite Dissolution Studies," Letter report WVST 86/104. West Valley Nuclear Services, West Valley, NY. 
- to determine the effect of zeolite particle size on cesium elution,

- to determine if aluminum can be used as an indicator for cesium in solution.

These objectives were addressed in 11 tests in which the amount of iron was varied, zeolite particle size was varied, nitrate and nitrite salts were added, and the oxalic acid solution was neutralized. The contact solution from each test was assayed for aluminum, cesium, and iron using ICP-MS. The amount of iron added to the system was decreased in one test to provide a lower bounding case for the amount of iron dissolved assuming that there is less rust present in tank 8D-1 than had been previously estimated. The zeolite particle size was decreased in one test to determine if grinding the zeolite in tank 8D-1 would allow more efficient cesium elution. Nitrate and nitrite salts were added in one test to simulate salts present as interstitial liquid in tank 8D-1 and to determine their affect on cesium elution. The oxalic acid solution was neutralized to simulate quenching of the acid in tank 8D-1 to minimize tank corrosion and to determine the affect on cesium elution. 


\subsection{Conclusions and Recommendations}

\subsection{Conclusions}

Eleven cesium elution tests were run in three batches. The tests conditions were: (1) control (recommended conditions from FY 1995 testing); (2) a lower concentration of $\mathrm{Fe}_{2} \mathrm{O}_{3}$, (3) concentrations of $\mathrm{NaNO}_{2}$ and $\mathrm{NaNO}_{3}$ equivalent to those in tank 8D-1, (4) $\mathrm{Fe}_{2} \mathrm{O}_{3}$ alone (no zeolite), (5) $\mathrm{Al}_{2} \mathrm{O}_{3}$ alone (no zeolite), (6 and 7) the oxalic acid neutralized with $\mathrm{NaOH}$ after 20 hours of contact, (8) zeolite particles ground to $<200$ mesh, (9) zeolite alone, (10) a carbon-steel coupon alone, and (11) cesium loading $\sim 3$ times higher than in previous testing.

Larger quantities of $\mathrm{Fe}_{2} \mathrm{O}_{3}$ tend to slow the cesium elution process at short contact times ( $<20$ hours). By the end of the tests ( 28 hours contact), however, the amounts of cesium eluted were all $\sim 90 \mathrm{wt} \%$ and within experimental error of one another, regardless of the initial amount of $\mathrm{Fe}_{2} \mathrm{O}_{3}$ present. After 28 hours, the amounts of iron in solution were within experimental error of each other at 34-39 wt\%. However, longer contact times may place larger amounts of iron in solution, as evidenced by the FY 1995 tests, in which $90 \mathrm{wt} \%$ of the added iron dissolved after 50 hours contact.

In tests with only zeolite and only carbon-steel coupons much less iron was in solution after 28 hours of contact with oxalic acid. However, in the zeolite only test, after 4 hours of contact, the amount of iron in solution was comparable to the control test. This suggests that iron dissolves at a certain rate regardless of the absolute amount present.

The presence of $\mathrm{NaNO}_{2}$ and $\mathrm{NaNO}_{3}$ in amounts equivalent to the concentration of these compounds in tank 8D-1 had no effect on cesium elution. However, the presence of the salts did decrease the amount of iron in solution by about $40 \%$. Therefore, the amount of iron that would dissolve in tank 8D-1 may not be as high as FY 1995 testing indicated. Tests with higher nitrite and nitrate levels and longer contact times are recommended.

Grinding the zeolite had no significant effect on the overall cesium elution, although elutions were slightly higher at short contact times because a larger surface area of zeolite was in contact with oxalic acid.

When zeolite was loaded with three times more cesium than the control, the percentage of cesium eluted was not significantly different from the control after 20 hours of contact ( $85 \mathrm{wt} \%$ in control vs. $82 \mathrm{wt} \%$ in high cesium loading). This shows that all of the data from the lower cesium loaded zeolite tests are still valid.

Neutralizing the oxalic acid with sodium hydroxide after 20 hours had little effect on the amount of cesium eluted, but neutralizing to $\mathrm{pH} 12.5$ decreased the amount of iron in solution. Therefore, neutralization may limit the amount of iron transferred to tank 8D-2 in the supernatant while having minimal impact on cesium elution. 
The mechanism for cesium elution may be a process by which aluminum and iron within the zeolite structure dissolve, creating a larger space around the cesium atoms. Aluminum is one of the principal components of zeolite IE-96; therefore, the amount of aluminum in solution might indicate the amount of zeolite dissolved and hence of the level of cesium elution. Comparison of percentages of aluminum and cesium showed the same trend in each test, indicating a correlation. At short contact times, the ratio of moles aluminum to moles cesium is very high. However, as contact time increases, the ratio decreases quickly to a constant value. Thus it may be that initially several aluminum atoms must be eluted from the structure of the zeolite to allow the cesium to escape, but as more aluminum is eluted, cesium escapes from the zeolite at a faster rate.

The results of the current testing, show that cesium can be successfully eluted from zeolite with oxalic acid. The objectives of this task were met by showing that adding salts will minimize the iron dissolution, neutralization with $\mathrm{NaOH}$ has no effect on the cesium elution but significantly decreases the amount of iron in solution and reducing zeolite particle size has no effect on the total cesium eluted from the zeolite.

\subsection{Recommendations}

The findings of this study lead to the following recommendations:

- that West Valley use $8 \mathrm{wt} \%$ oxalic acid at $40 \mathrm{~L} / \mathrm{kg}$ zeolite to elute the cesium from the remaining zeolite in tank 8D-1.

- a neutralization step with $\mathrm{NaOH}$ after 20 hours of acid contact to control dissolution of corrosion products in the tank, however, such neutralization produces a significant amount of precipitate (primarily sodium oxalate).

- three acid contacts be used. With only one acid contact, only $\sim 88 \mathrm{wt} \%$ of the cesium can be removed; with three contacts 99 wt\% of the cesium can be eluted as shown by the FY 1995 tests.

- several more tests be performed to further refine this process and to gain a thorough understanding of it, including: longer contact times with added salts and higher nitrite and nitrate levels. 


\subsection{Experimental Procedures}

\subsection{Zeolite Loading}

Zeolite IE-96 (see Table 3.1 for composition), manufactured by UOP ${ }^{(a)}$, was loaded to the desired level of cesium ( $922 \mu \mathrm{g} \mathrm{Cs} / \mathrm{g}$ zeolite) by contacting it with $\mathrm{CsNO}_{3}$ solution for 24-hours. The vessel in which the zeolite loading took place was kept at room temperature, and the solution and zeolite were agitated during the entire period to provide maximum contact of the zeolite with the $\mathrm{CsNO}_{3}$ solution. Appendix A contains the calculations of the required levels of cesium loading and the contact conditions for each set. After contact, the solution was decanted and the zeolite was placed in a drying oven at $\sim 105^{\circ} \mathrm{C}$ for 24 hours. A sample of the zeolite was analyzed by X-ray fluorescence (XRF) for cesium content. In the West Valley tank waste radioactive cesium is $30 \%$ of the total cesium on the zeolite. In one test, zeolite was loaded to a level that represented the total cesium loaded on the zeolite. The results for each batch are shown in Table 3.2.

When exposed to air, zeolite absorbs some of the moisture in the air, and for this reason, the loaded zeolite was stored in a drying oven at $110^{\circ} \mathrm{C}$. Weights of zeolite referred to in this report are dry weights, and thus no F-factor (dry weight/wet weight) calculation is necessary.

Table 3.1. Analysis of Zeolite IE-96

\begin{tabular}{l|c} 
Compound & wt $\%$ \\
\hline $\mathrm{Al}_{2} \mathrm{O}_{3}$ & 15.5 \\
$\mathrm{BaO}$ & 0.09 \\
$\mathrm{CaO}$ & 1.1 \\
$\mathrm{Fe}_{2} \mathrm{O}_{3}$ & 3.5 \\
$\mathrm{MgO}$ & 0.7 \\
$\mathrm{Na}_{2} \mathrm{O}$ & 7.0 \\
$\mathrm{MoO}_{3}$ & 0.03 \\
$\mathrm{SiO}_{2}$ & 60.1 \\
$\mathrm{SrO}^{\mathrm{TiO}}$ & 0.04 \\
$\mathrm{ZrO}_{2}$ & 0.03 \\
Other & 0.04 \\
$\mathrm{H}_{2} \mathrm{O}$ & 0.87 \\
Total & 11.0 \\
& 100
\end{tabular}

(a) UOP, Tarrytown, NY. 
Table 3.2. X-Ray Fluorescence Results for Cesium-Loaded Zeolite

\begin{tabular}{c|l}
$\mu \mathrm{g}$ Cs/g zeolite & \multicolumn{1}{|c}{ relevant tests } \\
\hline 922 & $30,31,32,35,37,40$ \\
995 & 36 (reduced particle size zeolite) \\
3615 & 39 (high Cs-loaded zeolite)
\end{tabular}

\subsection{Cesium-Elution Experiments: General Procedure}

The objective of this set of cesium elution tests was to refine the optimum process conditions by evaluating several variables. The baseline data were results of the two previous rounds of testing (Sills, et al. 1996) and additional engineering information received from West Valley Nuclear Services. Eight $\mathrm{wt} \%$ oxalic acid was used in all of these tests. WVNS calculated that the $100 \mathrm{~L}$ acid/kg zeolite used in the second round of FY 1995 testing would generate too much waste, and that $20 \mathrm{~L} / \mathrm{kg}$ would provide too little liquid to cover the zeolite in the tank; 40 to $60 \mathrm{~L}$ acid/kg zeolite is a more realistic range for the acid-to-zeolite ratio $^{(a)}$. Therefore, the previously defined optimum process ratio of $40 \mathrm{~L} \mathrm{acid} / \mathrm{kg}$ zeolite was used in these tests. In the FY 1995 testing, $2.77 \mathrm{~g}$ of $0.001 \mathrm{M} \mathrm{NaOH}$ was required to wet the $5 \mathrm{~g}$ of zeolite used in these tests (which is equivalent to $0.55 \mathrm{~L} 0.001 \mathrm{M} \mathrm{NaOH} / \mathrm{kg}$ zeolite). WVNS indicated that a more realistic approach would be to add a volume equivalent to $4 \mathrm{~L} 0.045 \mathrm{M} \mathrm{NaOH} / \mathrm{kg} \mathrm{zeolite}{ }^{(\mathrm{b})}$. The FY 1996 tests were scaled up to $10 \mathrm{~g}$ zeolite to help reduce the error involved by working with larger quantities. The bath temperature was $50^{\circ} \mathrm{C}$ and the acid addition temperature was $25^{\circ} \mathrm{C}$ (room temperature). FY 1995 results showed that most of the cesium elution occurs in the first few hours of contact; therefore, the contact length was shortened to 28 hours, and more sampling events were scheduled at shorter contact times. In previous tests, most of the cesium was eluted during the first acid contact; therefore, these tests were run with only a single acid contact. The test matrix is shown in Table 3.2.

The experiments were performed in $500 \mathrm{~mL}$ Pyrex ${ }^{\circledR}$ reaction vessels with ports for thermocouples, stir shafts, and sampling, as shown in Figure 3.1. Cesium-loaded zeolite was placed in the bottom of the reaction vessel and covered with $4 \mathrm{~L}$ of $0.045 \mathrm{M} \mathrm{NaOH} / \mathrm{kg}$ zeolite (to simulate the basic environment in tank $8 \mathrm{D}-1)$. The $8 \mathrm{wt} \%$ oxalic acid was then added at room temperature $\left(22\right.$ to $\left.25^{\circ} \mathrm{C}\right)$. The vessel was sealed with vacuum grease and placed in a heating mantle with a temperature controller programmed to hold at $50^{\circ} \mathrm{C}$ (the expected temperature of the material in tank $8 \mathrm{D}-1^{(\mathrm{c})}$ ). A stirring shaft was placed in each vessel and the contents of the vessel were agitated throughout the test period to simulate the effects of mixing pumps in tank 8D-1. Tests were run for 28 hours, and sampling was performed at 15 minutes, 30 minutes, $1,2,4,20$, and 28 hours of contact time, unless otherwise noted. During sampling, agitation was stopped and the material in the vessel was allowed to settle for five minutes. A $5 \mathrm{~mL}$ sample was then drawn from the supernatant and analyzed by inductively coupled plasma mass spectroscopy (ICPMS) for cesium, iron, and aluminum content.

(a) King, CS, fax to GK Patello dated January 29, 1996.

(b) Schiffhauer, MA, personal communication.

(c) Fahey, SC, fax to KD Wiemers dated October 20, 1994. 
Table 3.3. Test Matrix for FY96 Cesium Elution Tests

\begin{tabular}{llcrrr} 
& & \multicolumn{2}{c}{$\mathrm{NaOH}$} & Oxalic \\
\hline 30 & control & Zeolite, $g$ & \multicolumn{1}{c}{$\mathrm{Heel,g}$} & Acid, $g$ & $\mathrm{Fe}_{2} \mathrm{O}_{3}, \mathrm{~g}$ \\
31 & low $\mathrm{Fe}_{2} \mathrm{O}_{3}$ & 10 & 40 & 407.6 & 4.00 \\
$32^{*}$ & added salts & 10 & 40 & 407.6 & 2.00 \\
33 & pure $\mathrm{Fe}_{2} \mathrm{O}_{3}$ & 0 & 40 & 407.6 & 4.00 \\
$34^{* *}$ & pure $\mathrm{Al}_{2} \mathrm{O}_{3}$ & 0 & 0 & 1630.4 & 16.00 \\
35 & neutralization & 10 & 0 & 1630.4 & 0.00 \\
36 & small particles & 10 & 40 & 407.6 & 4.00 \\
37 & zeolite alone & 10 & 40 & 407.6 & 4.00 \\
38 & coupon alone & 0 & 40 & 407.6 & 0.00 \\
39 & high Cs & 10 & 40 & 407.6 & 0.00 \\
40 & neutralization & 10 & 40 & 407.6 & 4.00 \\
\hline
\end{tabular}

* Test 32 contained $0.36 \mathrm{~g} \mathrm{NaNO}_{2}$ and $0.11 \mathrm{~g} \mathrm{NaNO}_{3}$.

** Test 34 contained $16.00 \mathrm{~g} \mathrm{Al}_{2} \mathrm{O}_{3}$

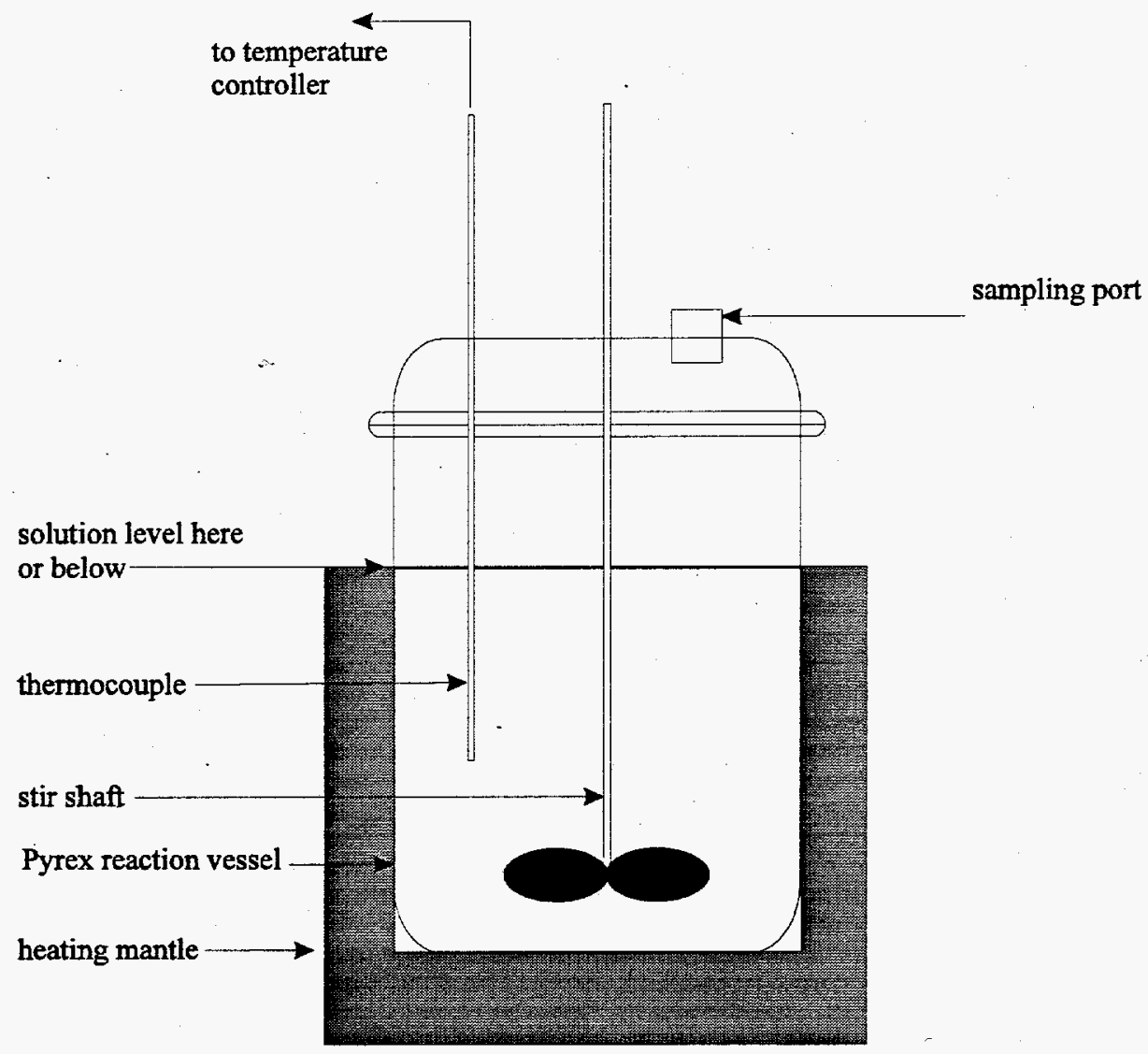

Figure 3.1. Reaction Vessel Assembly Used in Cesium Elution Tests 


\section{Control}

Test 30 was the control, setting the "standard conditions" for the FY1996 tests. Unlike the FY1995 tests, this control contained $4 \mathrm{~g}$ of $\mathrm{Fe}_{2} \mathrm{O}_{3}$ as a standard condition. The control was run at $40 \mathrm{~L}$ of $8 \mathrm{wt} \%$ oxalic acid/kg zeolite, and the tests were based on $10 \mathrm{~g}$ of zeolite. Final solids were collected for $\mathrm{x}$-ray diffraction (XRD) analysis. In addition, a sample of uncontacted zeolite and a sample of zeolite that had been contacted with oxalic acid for 28 hours with no $\mathrm{Fe}_{2} \mathrm{O}_{3}$ present were submitted for comparison.

\section{Reduced $\mathrm{Fe}_{2} \mathrm{O}_{3}$}

Test 31 contained half the amount of $\mathrm{Fe}_{2} \mathrm{O}_{3}$ added to the control to provide a lower bound case for evaluation. All previous tests have examined a "worst case" scenario. In all other respects, this test duplicated the control.

\section{Added Salts}

Test 32 was designed to examine the effect of $\mathrm{NaNO}_{2}$ and $\mathrm{NaNO}_{3}$ on cesium elution and iron dissolution. The salts were added to the reaction vessel in amounts that would bring the total $\mathrm{NO}_{2}{ }^{-}$and $\mathrm{NO}_{3}{ }^{-}$concentrations to the same level as those found in tank 8D-1: $6000 \mu \mathrm{g} \mathrm{NO}_{2}{ }^{-1} \mathrm{~g}$ of solution, and $2000 \mu \mathrm{g} \mathrm{NO}_{3}{ }^{-} / \mathrm{g}$ of solution ${ }^{(\mathrm{a})}$.

\section{Pure Compounds}

Tests 33 and 34 were designed to provide a baseline by examining the dissolution behavior of the pure compounds $\mathrm{Fe}_{2} \mathrm{O}_{3}$ and $\mathrm{Al}_{2} \mathrm{O}_{3}$, respectively, in $8 \mathrm{wt} \%$ oxalic acid. By comparing these results with the results of the combined reactants, it could be determined if the mixture has an effect on the individual rates of dissolution. These tests were run in two-liter reaction vessels, and amounts of reagents were based on $40 \mathrm{~g}$ of zeolite, although no zeolite was actually added to either vessel. Test 33 contained $16 \mathrm{~g}$ of $\mathrm{Fe}_{2} \mathrm{O}_{3}$, and Test 34 contained $16 \mathrm{~g}$ of $\mathrm{Al}_{2} \mathrm{O}_{3}$.

\section{Neutralization}

Tests 35 and 40 examined the effect of neutralizing the oxalic acid with $\mathrm{NaOH}$ on iron dissolution and cesium elution. The initial test conditions were identical to the control, but after 20 hours of contact with $8 \mathrm{wt} \%$ oxalic acid, $10 \mathrm{M} \mathrm{NaOH}$ was added to the reaction vessel to raise the $\mathrm{pH}$ to $\sim 12$ for Test 35 , and $\sim 5$ for Test 40 . Samples were taken at 15 minutes, 30 minutes, 1 hour, 2 hours, and 4 hours after $\mathrm{pH}$ stabilization. At the end of the experiments, the remaining solids were collected, weighed, and submitted for XRD analysis.

\section{Reduced Particle Size Zeolite}

Test 36 examined the effect of using smaller particles of zeolite. The zeolite was ground in the laboratory, sieved to -200 mesh, and analyzed by XRF to confirm that the cesium loading had not

(a) King, CS, fax to GK Patello dated December 8, 1995. 
changed significantly. In all other respects, the conditions for this test were identical to the control. After the last sampling event, the remaining solids and a sample of the initial ground zeolite were submitted for particle size analysis.

\section{Zeolite and Coupons}

The dissolution of zeolite alone in $8 \mathrm{wt} \%$ oxalic acid was examined in Test 37 , and the dissolution of a carbon steel coupon in $8 \mathrm{wt} \%$ oxalic acid was examined in Test 38. In Test 37, the only source of iron was the zeolite, and in Test 38, the only source of iron was the coupon. These tests were conducted to determine if iron from different sources (i.e., zeolite, carbon steel, and $\mathrm{Fe}_{2} \mathrm{O}_{3}$ ) had different rates of dissolution.

\section{High Cesium Loading}

Test 39 examined the effect of loading zeolite to about three times the cesium level used in previous experiments. This cesium loading corresponds more closely to the loading of the zeolite in tank 8D-1. In all other respects, the conditions for this test were identical to the control.

\subsection{Particle Size Analysis}

Particle size analysis with a Microtrac FRA particle size analyzer was performed on the ground zeolite both before and after oxalic acid contact. A representative sample of the zeolite was diluted $(\sim 10$ times) with deionized water and injected into the sample chamber of the analyzer. This technique was not used on the unground zeolite because the particle size $(\sim 200-500 \mu \mathrm{m})$ was outside the instrument's capability.

Before and after oxalic acid contact, samples of ground and unground zeolite were sprinkled on a glass slide and examined with an Olympus PMG3 optical microscope with magnification in the range of $10 \mathrm{X}$ to $100 \mathrm{X}$. This technique was used in a qualitative manner only to observe changes to the zeolite structure. 



\subsection{Results and Discussion}

\subsection{Effect of Amounts and Types of Iron}

The amount of cesium eluted in Tests 30 (control), 31 (reduced $\mathrm{Fe}_{2} \mathrm{O}_{3}$ ), and 37 (zeolite alone), which contained 4, 2, and $0 \mathrm{~g} \mathrm{Fe}_{2} \mathrm{O}_{3}$, respectively, are shown in Table 4.1, and the data are plotted in Figure 4.1. Test 17 from FY 1995 which also contained $4 \mathrm{~g} \mathrm{Fe}_{2} \mathrm{O}_{3}$ but only $5 \mathrm{~g}$ of zeolite is also included for comparison. All values in the tables throughout the report have an estimated $\pm 10 \%$ uncertainty due to analytical error. Temperature and $\mathrm{pH}$ data for all of the tests are in Appendix C. In Appendix D sample calculations show the method by which raw data were converted to $w t \%$ cesium eluted. The data were corrected for sample removal; as shown in the calculations in Appendix D. The amount of cesium eluted after 28 hours contact in Tests 31 and 37 are within experimental error of the control (Figure 4.1). Although the amounts of cesium eluted after 28 hours are essentially the same in all four tests $(\sim 90 \mathrm{wt} \%)$, larger amounts of $\mathrm{Fe}_{2} \mathrm{O}_{3}$ slowed the overall cesium elution rate at the shorter contact times ( $<20$ hours) in the FY 1996 tests. These tests compare favorably with the control from the FY 1995 testing which showed that $\sim 91 \mathrm{wt} \%$ of the cesium was eluted from the zeolite after 28 hours even though less zeolite and $\mathrm{NaOH}$ were used. However, using less $\mathrm{NaOH}$ seems to have increased the rate at which the cesium is eluted at short contact times.

Table 4.1. Weight Percent Cesium Eluted in Tests to Determine Effects of Iron on Cesium Elution

\begin{tabular}{cc|cccc} 
sample & hours & $\begin{array}{c}\text { control } \\
\text { (FY 1996) } \\
\text { Test 30 }\end{array}$ & Test 31 & Test 37 & $\begin{array}{c}\text { zeolite } \\
\text { control } \\
\text { Test 17 }\end{array}$ \\
\hline T1 & 0.25 & 4.45 & 3.51 & 1.38 & - (a) $^{\text {(a) }}$ \\
T2 & 0.5 & 9.02 & 12.5 & 9.23 & - (a) $^{\text {(a) }}$ \\
T3 & 1 & 21.2 & 26.9 & 34.4 & $-{ }^{2}$ \\
T4 & 2 & 38.1 & 54.4 & 80.2 & 68 \\
T5 & 4 & 50.9 & 69.7 & 89.5 & 82 \\
T6 & 20 & 84.7 & 86.9 & 89.5 & 100 \\
T7 & 28 & 87.8 & 92.3 & 81.8 & 91 \\
\hline
\end{tabular}

(a) Not measured.

The amount of iron dissolved in these tests and in Test 33, which contained pure $\mathrm{Fe}_{2} \mathrm{O}_{3}$, are shown in Table 4.2 and Figure 4.2. In the tests containing added $\mathrm{Fe}_{2} \mathrm{O}_{3}(-325 \mathrm{mesh}), 34$ to $39 \mathrm{wt} \%$ of the total iron in the system dissolved in 28 hours, regardless of the amount of $\mathrm{Fe}_{2} \mathrm{O}_{3}$ added to the system. In Test 37, which contained zeolite alone, $86 \mathrm{wt} \%$ of the iron from the zeolite structure was in solution after 28 hours, which supports FY 1995 findings that $91 \mathrm{wt} \%$ of the iron in the zeolite is in solution after 28 hours. 


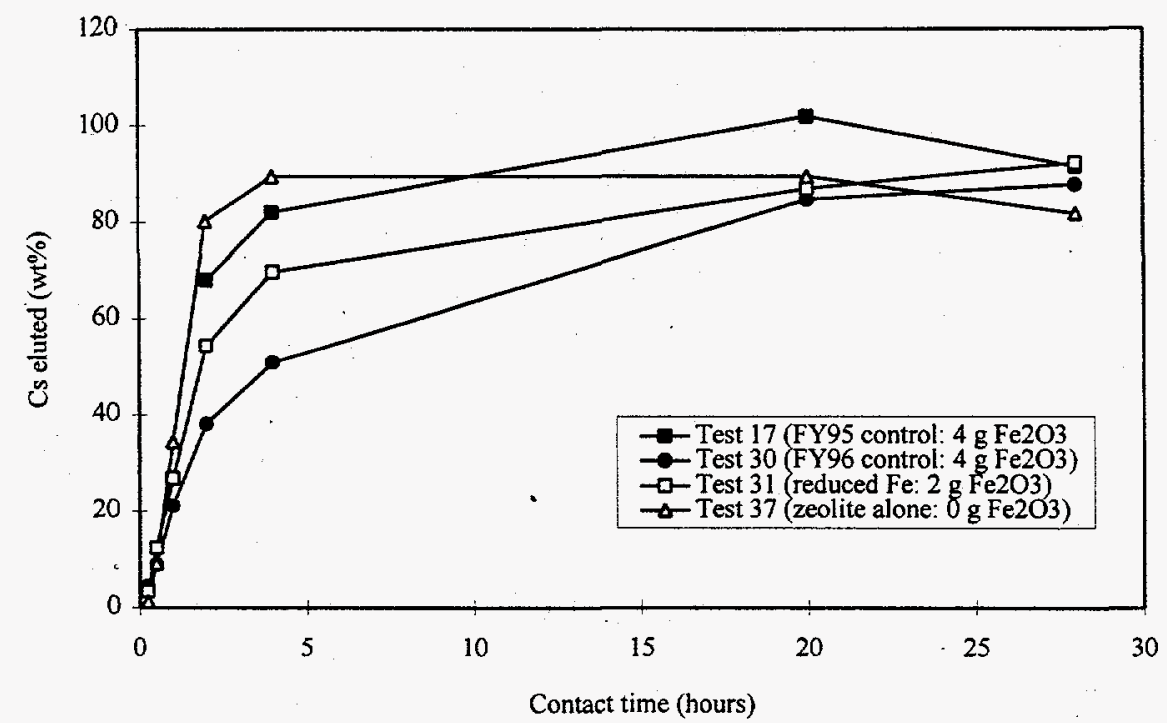

Figure 4.1. Percent Cesium Eluted in Tests Containing Various Amounts of $\mathrm{Fe}_{2} \mathrm{O}_{3}$ $(100 \%=$ Total Amount of Cesium Loaded onto Zeolite)

Table 4.2. Percent Iron Dissolved in Tests Containing Iron in Various Amounts and Forms

\begin{tabular}{|c|c|c|c|c|c|c|}
\hline & Total Fe & $\begin{array}{c}\text { control } \\
\text { (FY 1996) } \\
2.7977 \mathrm{~g}\end{array}$ & $\begin{array}{c}<\mathrm{Fe} \\
1.3989 \mathrm{~g}\end{array}$ & $\begin{array}{c}\text { pure } \\
\mathrm{Fe}_{2} \mathrm{O}_{3} \\
11.20 \mathrm{~g}\end{array}$ & zeolite & $\begin{array}{c}\text { control } \\
\text { (FY 1995) } \\
2.8886 \mathrm{~g}\end{array}$ \\
\hline sample & hours & Test 30 & Test 31 & Test 33 & Test 37 & Test 17 \\
\hline T1 & 0.25 & 1.22 & 2.97 & 1.56 & 1.17 & $--^{(a)}$ \\
\hline $\mathrm{T} 2$ & 0.5 & 1.01 & 2.99 & 0.94 & 11.0 & .. (a) \\
\hline $\mathrm{T} 3$ & 1 & 1.88 & 4.03 & 2.63 & 28.7 & $-^{\text {(a) }}$ \\
\hline T4 & 2 & 3.31 & 7.32 & 4.65 & 49.9 & 2.8 \\
\hline T5 & 4 & 5.15 & 9.65 & 4.80 & 55.7 & 6.2 \\
\hline T6 & 20 & 24.4 & 27.0 & 25.0 & 104 & 5.1 \\
\hline T7 & 28 & 33.7 & 38.6 & 38.5 & 85.5 & 63 \\
\hline
\end{tabular}

(a) Not measured.

The FY 1996 results are also compared to those of FY 1995 in Figure 4.2. In Test 17, conducted in FY 1995, $63 \mathrm{wt} \%$ of the iron had dissolved after 28 hours of contact. It is most likely that either this point or the 20 hour contact point is aberrant because the FY 1996 results show a maximum iron dissolution of $39 \mathrm{wt} \%$ for similar tests. Longer contact times under the conditions examined in the FY 1996 tests may result in more dissolution of iron because the iron concentrations are still increasing slightly after 28 hours. 


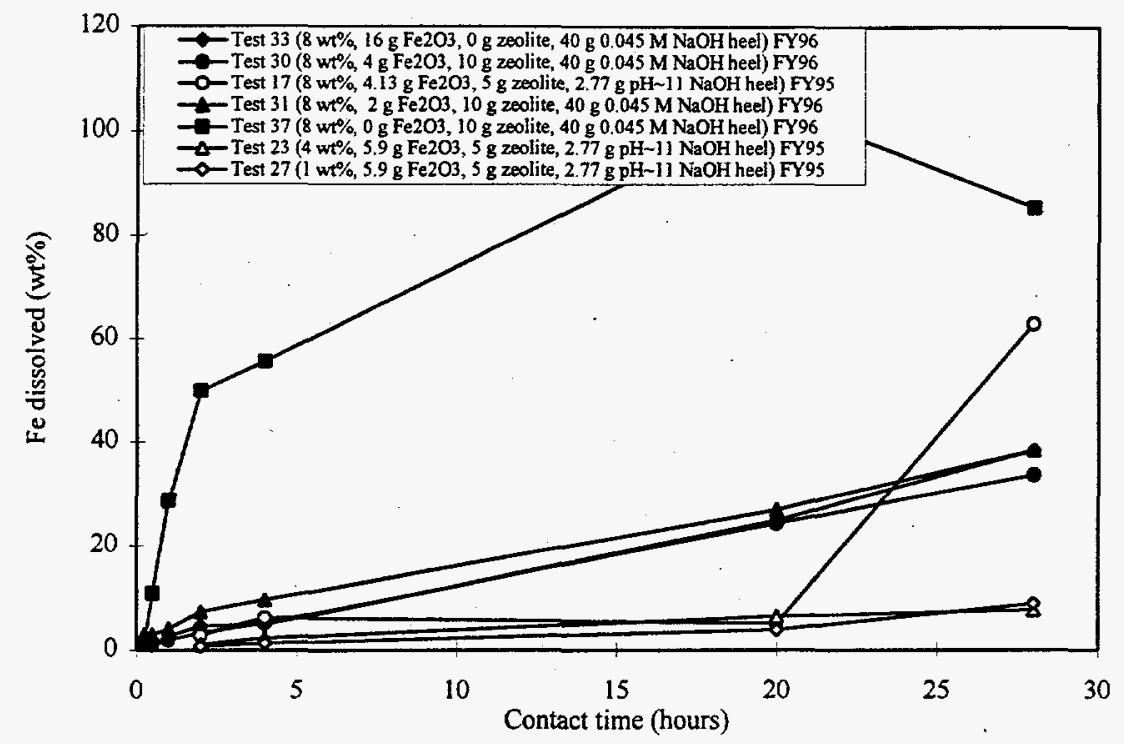

Figure 4.2. Percent Iron Dissolved in Tests Containing Iron in Various Forms and Amounts $(100 \%=$ Total Amount of Iron in the System)

In comparing the results of FY 1995 and FY 1996 testing, it is important to note some basic differences in the two sets of tests. The $\mathrm{NaOH}$ heel used in FY1996 tests was much larger-- $40 \mathrm{~g}$ of $0.045 \mathrm{M}$ $\mathrm{NaOH}$, as opposed to $2.77 \mathrm{~g}$ of $0.001 \mathrm{M} \mathrm{NaOH}$ used in the FY 1995 tests. Also, FY 1995 tests were scaled to $5 \mathrm{~g}$ zeolite; FY 1996 tests, to $10 \mathrm{~g}$. Therefore, a total of $7.2 \mathrm{mg} \mathrm{NaOH} / \mathrm{g}$ zeolite in the FY 1996 tests must be compared to $0.02 \mathrm{mg} \mathrm{NaOH} / \mathrm{g}$ zeolite in the FY 1995 tests (see Appendix A for calculations). Later results in Section 4.2 show that added salts decrease iron dissolution. Adding $\mathrm{NaOH}$ to the system may have a similar effect and thereby explain the finding that a lower percent iron was dissolved at 28 hours in the FY 1996 tests than in the FY 1995 tests.

Additionally, FY1995 Tests 23 and 27 contained more iron per gram of zeolite than the FY 1996 tests, but Test 23 was run in $4 \mathrm{wt} \%$ oxalic acid, and Test 27 was run in $1 \mathrm{wt} \%$ oxalic acid. These tests show that increasing the concentration of oxalic acid from 1 to $8 \mathrm{wt} \%$ increases iron dissolution.

The amount of iron in solution ( $\mu \mathrm{g}$ iron/g solution) at each sampling event is shown in Table 4.3. The data are also plotted in Figure 4.3 to compare the amount of iron in solution from the coupons and from the other tests. In Tests 37 and 38, which contained only zeolite and only coupons, respectively, much less iron than in the control was in solution after 28 hours of contact. Thus, most of the iron in solution apparently comes from dissolved $\mathrm{Fe}_{2} \mathrm{O}_{3}$, which may be present as rust in the bottom of the tanks, and not from the zeolite. In the zeolite only test, the amount of iron in solution until 4 hours contact is close to the control level. This finding may indicate that iron dissolves at a certain rate regardless of the absolute amount present. The zeolite does not keep pace with the control at 20 and 28 hours contact because the iron in the zeolite is depleted ( $85.5 \mathrm{wt} \%$ of the iron was eluted after 28 hours in the zeolite only test). The close comparison between the pure $\mathrm{Fe}_{2} \mathrm{O}_{3}$ test and the control throughout the test further suggests that most of the dissolved iron comes from the added iron (simulated corrosion product) and not from the zeolite. This is expected because the amount of corrosion product far exceeds the amount of iron present in the zeolite. 
Table 4.3. Concentrations of Iron in Solution $(\mu \mathrm{g} / \mathrm{g})$ in Tests Containing Iron in Various Forms

\begin{tabular}{cc|rrrrr} 
sample & hours & $\begin{array}{l}\text { control } \\
\text { Test 30 }\end{array}$ & $\begin{array}{l}<\mathrm{Fe} \\
\text { Test 31 }\end{array}$ & $\begin{array}{l}\text { pure } \mathrm{Fe}_{2} \mathrm{O}_{3} \\
\text { Test 33 }\end{array}$ & $\begin{array}{l}\text { zeolite } \\
\text { Test 37 }\end{array}$ & $\begin{array}{l}\text { coupons } \\
\text { Test 38 }\end{array}$ \\
\hline T1 & 0.25 & 83.3 & 109 & 107 & 6.41 & 2.60 \\
T2 & 0.5 & 68.5 & 110 & 64.4 & 60.7 & 6.93 \\
T3 & 1 & 129 & 149 & 181 & 160 & 15.3 \\
T4 & 2 & 230 & 274 & 322 & 280 & 26.4 \\
T5 & 4 & 361 & 364 & 332 & 313 & 35.0 \\
T6 & 20 & 1750 & 1040 & 1740 & 598 & 196 \\
T7 & 28 & 2430 & 1500 & 2690 & 485 & 300
\end{tabular}

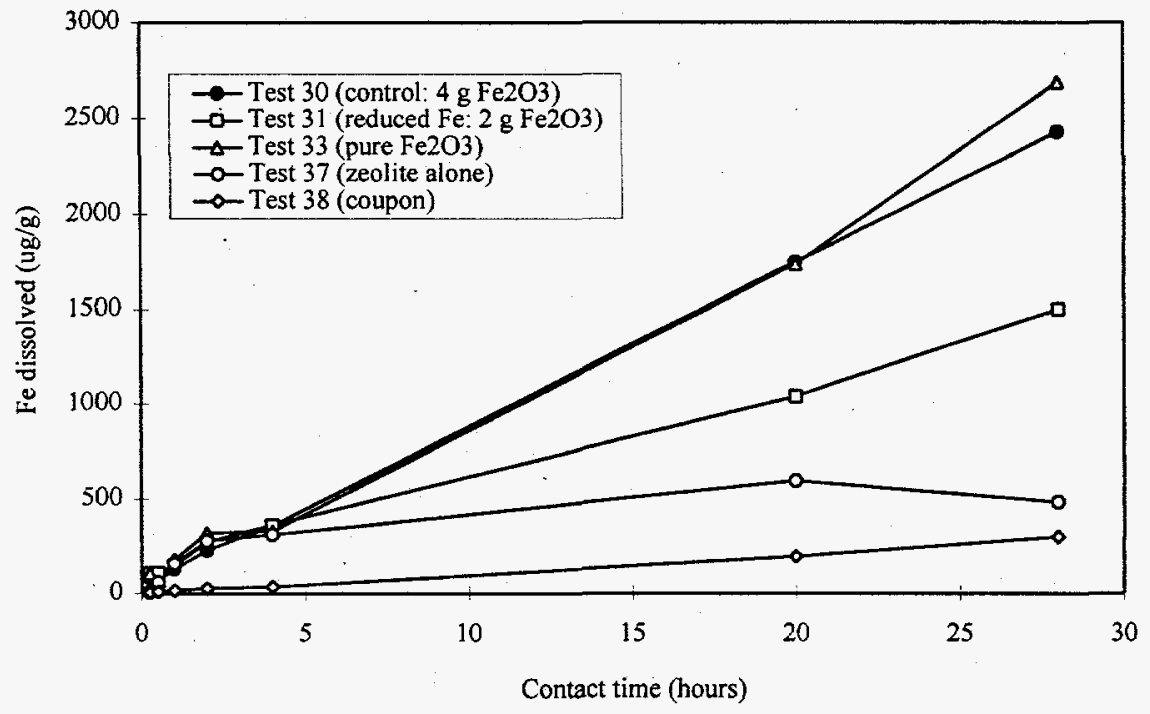

Figure 4.3. Concentrations of Iron in Solution $(\mu \mathrm{g} / \mathrm{g})$ in Tests Containing Iron in Various Amounts and Forms

\subsection{Effect of the Presence of Salts}

Test 32 contained $\mathrm{NaNO}_{2}$ and $\mathrm{NaNO}_{3}$ in amounts equivalent to the nitrite and nitrate levels found in tank 8D-1. The amount of cesium eluted in Tests 30 (control) and 32 (added salts) are shown in Table 4.4 and plotted in Figure 4.4 . Within the bounds of experimental error $( \pm 10 \%)$, the presence of salts appears to have no effect on cesium elution. 
Table 4.4. Weight Percent Cesium Eluted in Tests 30 and 32 to Determine the Effect of Salts on Cesium Elution

\begin{tabular}{cc|cc} 
sample & hours & $\begin{array}{c}\text { control } \\
\text { Test 30 }\end{array}$ & $\begin{array}{c}\text { salts } \\
\text { Test 32 }\end{array}$ \\
\hline T1 & 0.25 & 4.45 & 1.97 \\
T2 & 0.5 & 9.02 & 9.33 \\
T3 & 1 & 21.2 & 22.4 \\
T4 & 2. & 38.1 & 40.9 \\
T5 & 4 & 50.9 & 50.0 \\
T6 & 20 & 84.7 & 78.7 \\
T7 & 28 & 87.8 & 87.8
\end{tabular}

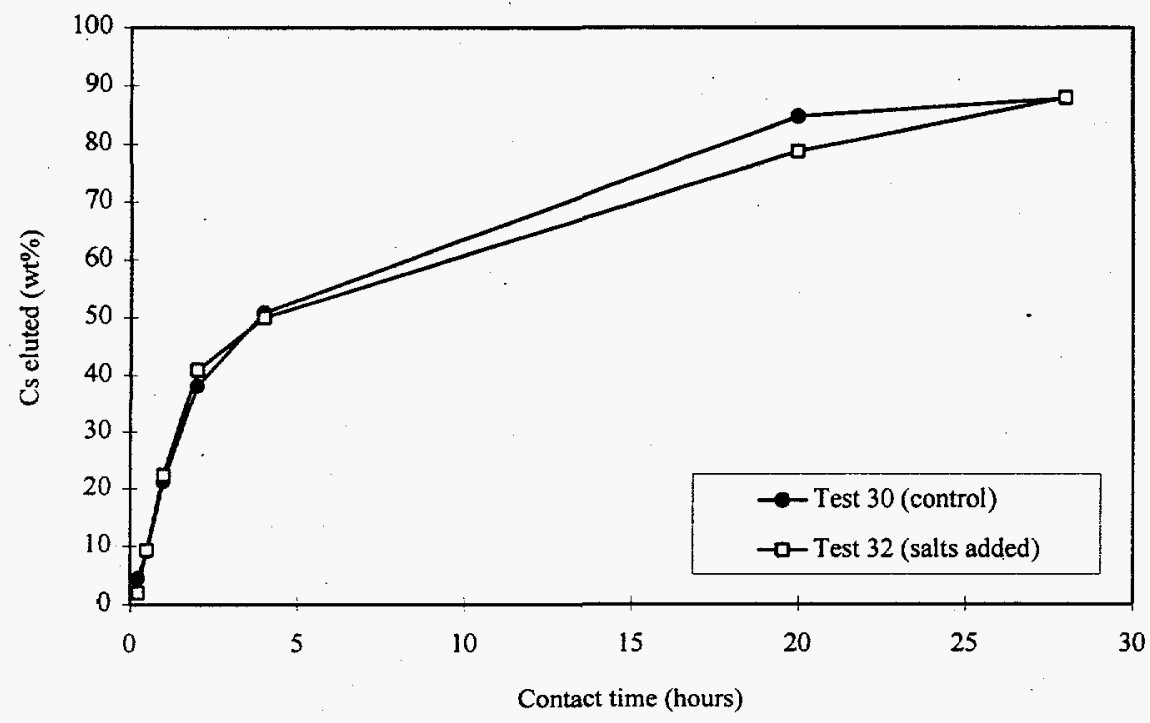

Figure 4.4. Weight Percent Cesium Eluted in Tests 30 and 32 to Determine the Effect of $\mathrm{NaNO}_{2}$ and $\mathrm{NaNO}_{3}$ Salts on Cesium Elution

The effect of salts on the dissolution of iron is shown in Table 4.5 and in Figure 4.5 by comparison to the control (Test 30). During the first four hours of contact, the presence of salts has no significant effect on the dissolution of iron; however, at 20 and 28 hours contact, significantly less iron was dissolved in the presence of salts (Test 32) than in the control (Test 30). After 28 hours contact, only $21 \mathrm{wt} \%$ of the iron had dissolved in the salts test, compared to $34 \mathrm{wt} \%$ in the control. Since nitrate and nitrite are present in tank 8D-1 in the concentrations used in Test 32, these data suggest that the amount of iron dissolved during cesium elution with oxalic acid may not be as high as FY 1995 testing indicated. This may have positive implications for rust dissolution. Not as much iron as previously thought may be going into the melter feed flowsheet. It is recommended to run these tests for longer times to determine whether the presence of salts would slow iron dissolution or halt the process after a certain time. 
Table 4.5. Percentage of Iron Dissolved in Tests 30 and 32 to Determine the Effect of Salts on Cesium Elution

\begin{tabular}{cc|cc} 
sample & hours & $\begin{array}{c}\text { control } \\
\text { Test 30 }\end{array}$ & $\begin{array}{c}\text { salts } \\
\text { Test 32 }\end{array}$ \\
\hline T1 & 0.25 & 1.22 & 1.85 \\
T2 & 0.5 & 1.01 & 1.17 \\
T3 & 1 & 1.88 & 2.07 \\
T4 & 2 & 3.31 & 2.98 \\
T5 & 4 & 5.15 & 4.56 \\
T6 & 20 & 24.4 & 12.5 \\
T7 & 28 & 33.7 & 21.0
\end{tabular}

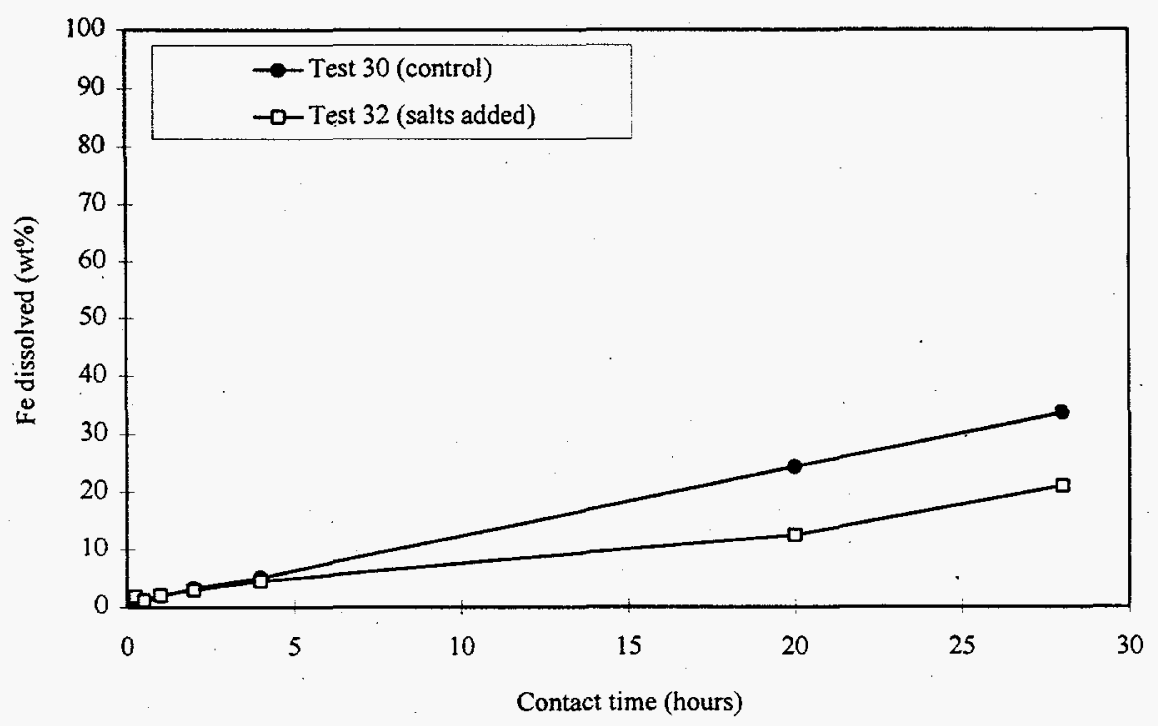

Figure 4.5. Percentage of Iron Dissolved in Tests 30 and 32 to Determine the Effect of $\mathrm{NaNO}_{2}$ and $\mathrm{NaNO}_{3}$ Salts on Cesium Elution

\subsection{Effect of Reduced Particle Size Zeolite}

Test 36 examined the effect of reducing the particle size of the loaded zeolite on cesium elution. The loaded zeolite (estimated particle size range of $240-420 \mu \mathrm{m}$ ), was ground and passed through a sieve so that only particles less than 75 um (-200 mesh) were used. The zeolite used in the West Valley columns was $\sim 300 \mu \mathrm{m}^{\text {(a) }}$. Table 4.6 and Figure 4.6 compare the cesium elution data from Test 36 with that of Test 30 (control). Higher cesium elution levels in the test with the ground zeolite at short contact times indicate that grinding the zeolite initially increases the rate of cesium elution. However, after 20 hours,

(a) Schiffhauer, MA, personal communication. 
Table 4.6. Weight Percent Cesium Eluted in Test Containing Reduced Particle Size Zeolite

\begin{tabular}{cc|cc} 
sample & hours & $\begin{array}{c}\text { control } \\
\text { Test 30 }\end{array}$ & $\begin{array}{c}\text { red. part. } \\
\text { Test 36 }\end{array}$ \\
\hline T1 & 0.25 & 4.45 & 23.6 \\
T2 & 0.5 & 9.02 & 34.0 \\
T3 & 1 & 21.2 & 47.3 \\
T4 & 2 & 38.1 & 55.4 \\
T5 & 4 & 50.9 & 64.2 \\
T6 & 20 & 84.7 & 80.7 \\
T7 & 28 & 87.8 & 86.1
\end{tabular}

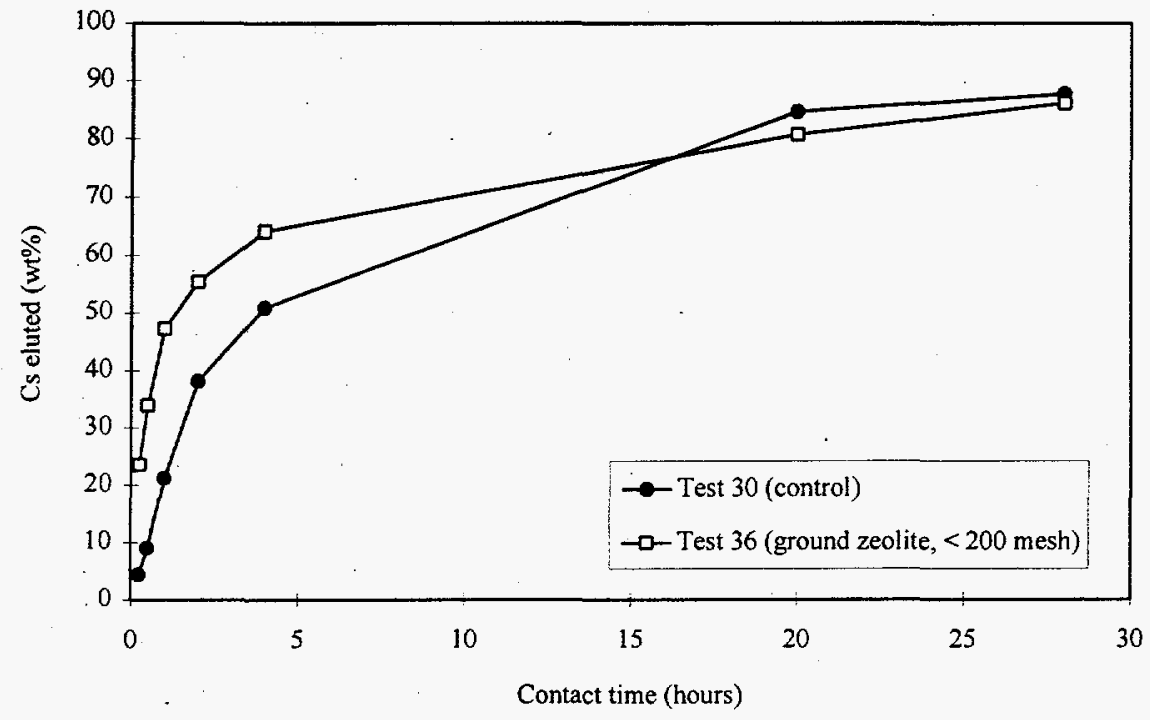

Figure 4.6. Weight Percent Cesium Eluted in Test Containing Reduced Particle Size Zeolite

the amount of cesium eluted in the reduced particle size test was within experimental error of the control. The greater cesium elution on the ground zeolite at shorter contact times is not surprising because a much greater surface area of zeolite is exposed to the oxalic acid solution. At longer times, however, an equilibrium is reached and therefore, the amount of cesium eluted is approximately the same.

Iron dissolution in Test 36 (reduced particle size zeolite) and Test 30 (control) is shown in Table 4.7 and plotted in Figure 4.7. The amount of iron in solution for the ground zeolite test is within experimental error of the control. Grinding the zeolite was not anticipated to affect the dissolution of iron because most of the iron is suspected to be coming from the $\mathrm{Fe}_{2} \mathrm{O}_{3}$ and not the zeolite. 
Table 4.7. Effect of Reduced Particle Size Zeolite on Iron Dissolution During Cesium Elution Tests

\begin{tabular}{cc|rc} 
sample & hours & $\begin{array}{r}\text { control } \\
\text { Test 30 }\end{array}$ & $\begin{array}{l}\text { red. part. } \\
\text { Test 36 }\end{array}$ \\
\hline T1 & 0.25 & 1.22 & 1.53 \\
T2 & 0.5 & 1.01 & 1.79 \\
T3 & 1 & 1.88 & 3.19 \\
T4 & 2 & 3.31 & 2.93 \\
T5 & 4 & 5.15 & 4.42 \\
T6 & 20 & 24.4 & 23.2 \\
T7 & 28 & 33.7 & 31.8
\end{tabular}

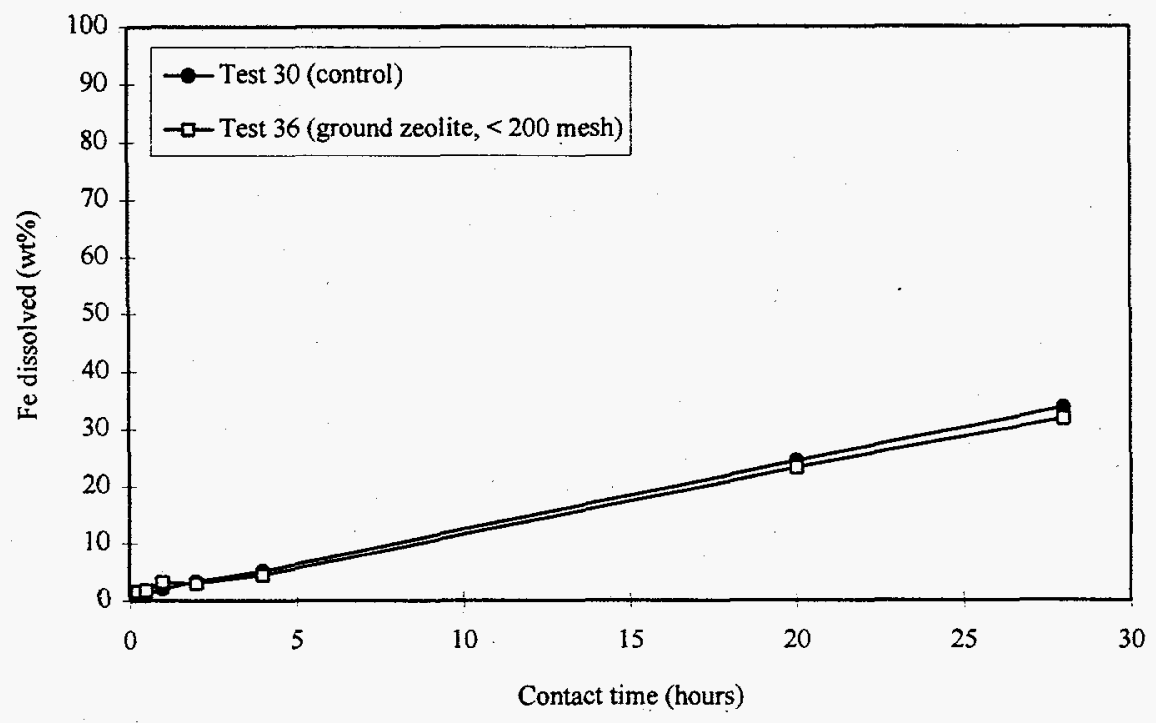

Figure 4.7. Effect of Reduced Particle Size Zeolite on Iron Dissolution During Cesium Elution Tests

\subsection{Particle Size Analysis of the Zeolite}

Particle size analysis was performed on the ground zeolite before and after contact with oxalic acid. The particle size distribution before and after oxalic acid contact based on an equivalent spherical diameter is plotted in Figures 4.8 and 4.9. The distribution curves before and after acid contact seem to be trimodal and bimodal, respectively. Before contact with oxalic acid, $10 \%$ of the particles are smaller than $2.80 \mu \mathrm{m}, 50 \%$ are smaller than $22.33 \mu \mathrm{m}$ and $90 \%$ are smaller than $66.67 \mu \mathrm{m}$. After contact, $10 \%$ of the particles are smaller than $3.72 \mu \mathrm{m}, 50 \%$ are smaller than $20.88 \mu \mathrm{m}$ and $90 \%$ are smaller than $57.01 \mu \mathrm{m}$. Thus the acid may dissolve some of the finer zeolite dust from grinding but it does not reduce 


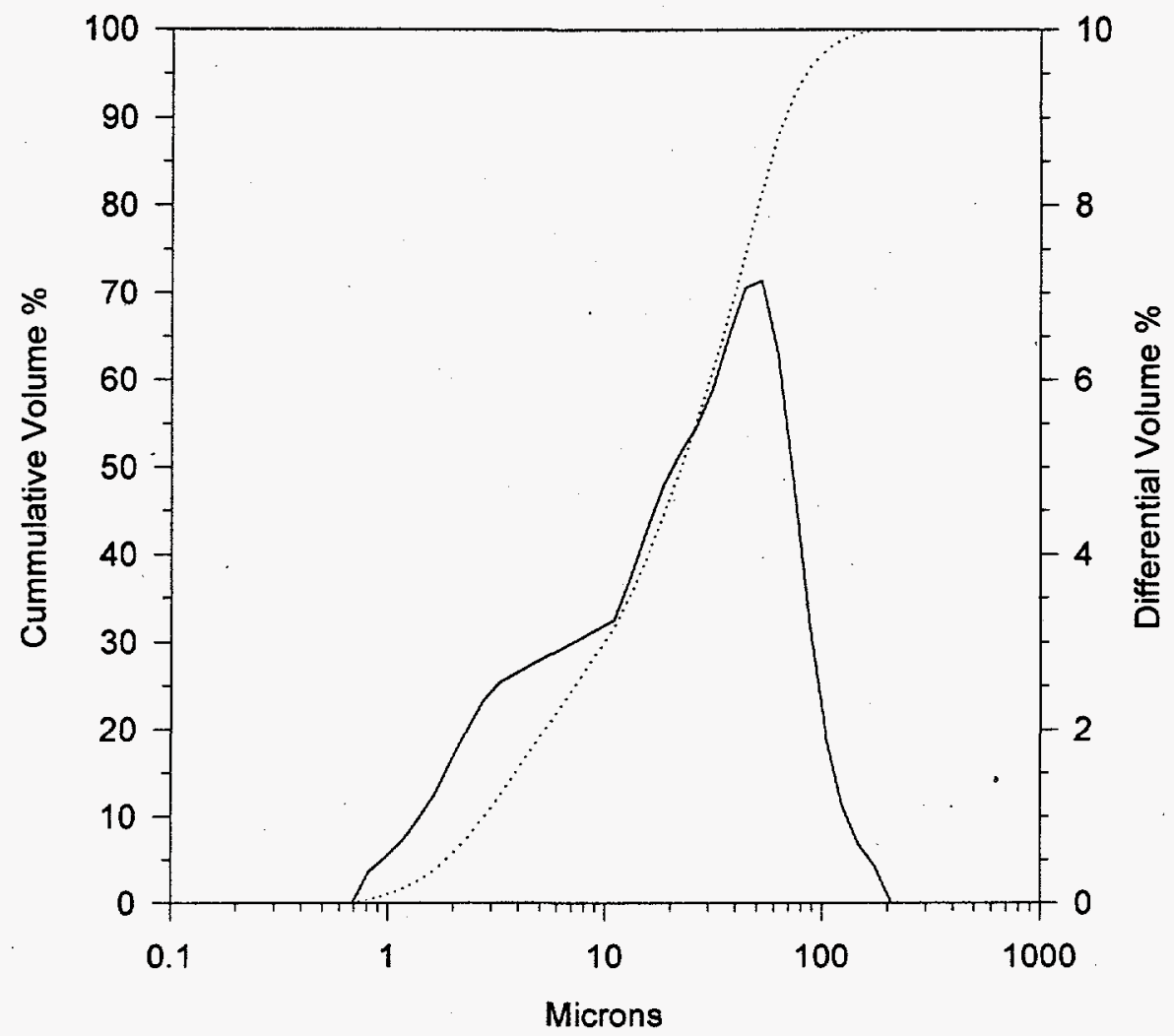

Figure 4.8. Zeolite Particle Size Before Acid Dissolution

\subsection{Zeolite Loaded to a Higher Level of Cesium}

Test 39 examined the effect on cesium elution of increasing cesium loading on the zeolite. The zeolite was loaded to $3615 \mu \mathrm{g}$ cesium/g zeolite in Test 39 versus $922 \mu \mathrm{g}$ cesium/g zeolite in most other experiments. The results of this test and the control (Test 30) are shown in Table 4.8 and Figure 4.10. This test became necessary after Lane Bray of PNNL revealed that only cesium-137 had been addressed in the cesium loading calculations and that it accounted for only $\sim 30 \%$ of total cesium ${ }^{\text {(a) }}$. Therefore, the calculated cesium level was only about one-third of the actual cesium level in tank 8D-1. Test 39 was run to determine whether the cesium elution behavior was affected by increasing the cesium loading of the zeolite to the proper level. Figure 4.10 shows that the amount of cesium eluted in Test 39 is within experimental error of the control.

The amounts of iron dissolved in Test 39 and in Test 30 (control) in Table 4.9 and Figure 4.11. At longer contact times ( 20 and 28 hours), the amount of iron dissolved was slightly higher in the test than in the control. This result is unexpected as the amount of cesium in the zeolite should not affect the dissolution of loose $\mathrm{Fe}_{2} \mathrm{O}_{3}$, the source of most of the iron in solution. At shorter contact times, the amount of iron dissolved in Test 39 was within experimental error of the control.

(a) Bray, LA, personal communication. 


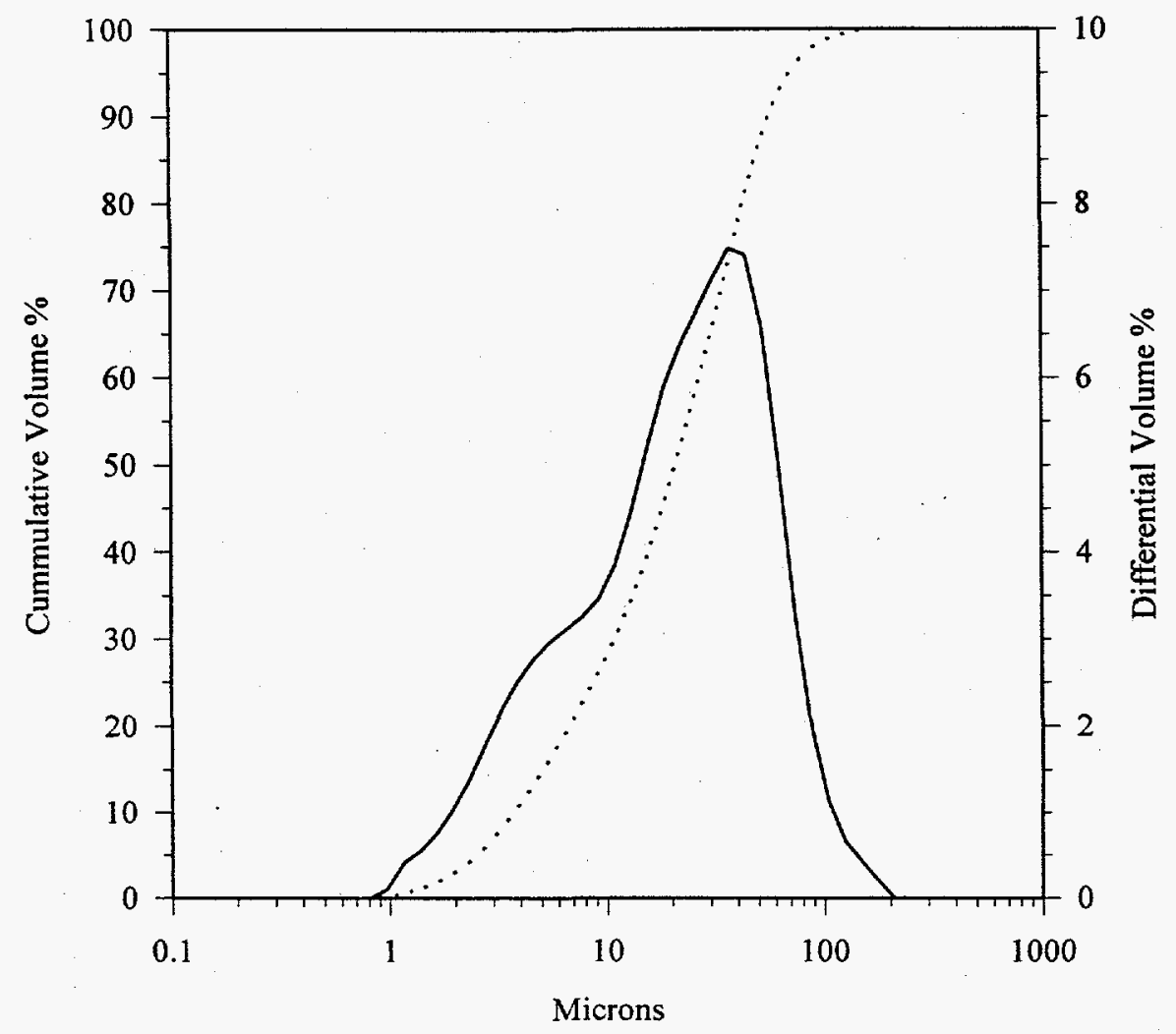

Figure 4.9. Zeolite Particle Size After Acid Dissolution

Table 4.8. Weight Percent Cesium Eluted in Test to Determine the Effect of Using Higher Cesium-Loaded Zeolite on Cesium Elution

\begin{tabular}{cc|cc} 
sample & hours & $\begin{array}{c}\text { control } \\
\text { Test 30 }\end{array}$ & $\begin{array}{c}\text { high Cs } \\
\text { Test 39 }\end{array}$ \\
\hline T1 & 0.25 & 4.45 & 1.73 \\
T2 & 0.5 & 9.02 & 5.57 \\
T3 & 1 & 21.2 & 13.5 \\
T4 & 2 & 38.1 & 24.4 \\
T5 & 4 & 50.9 & 47.2 \\
T6 & 20 & 84.7 & 81.8 \\
T7 & 28 & 87.8 & 78.5
\end{tabular}




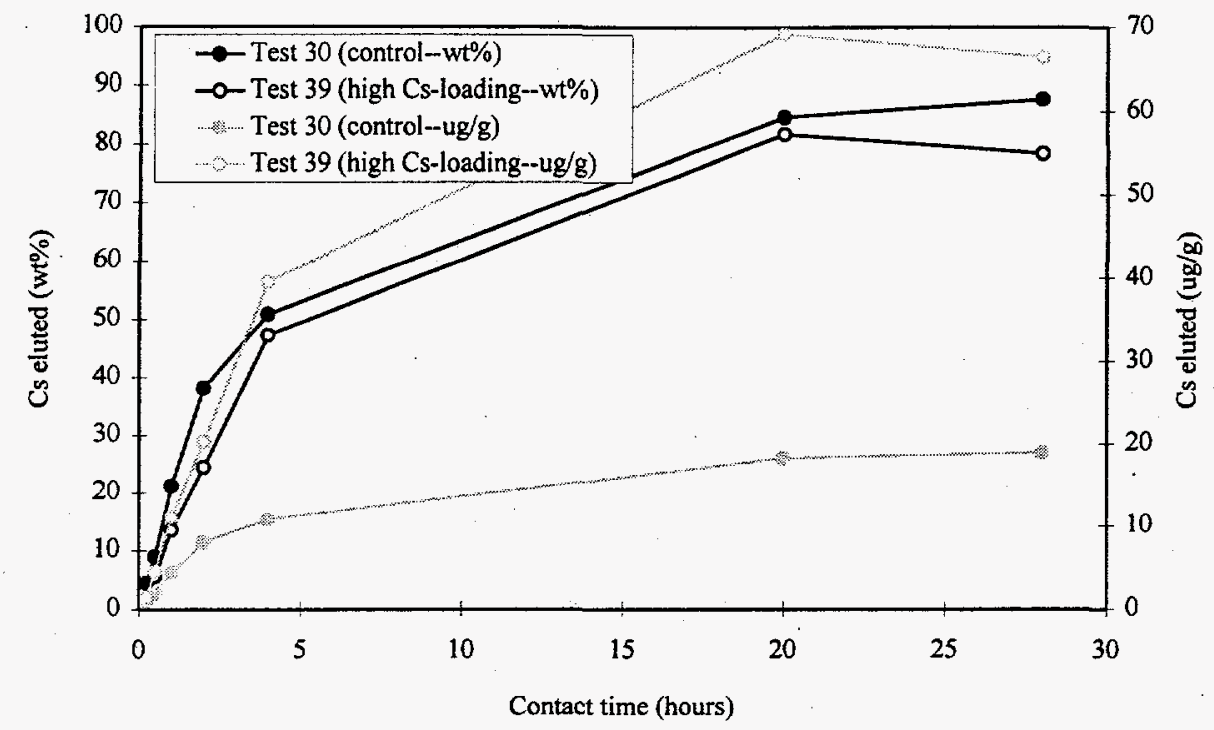

Figure 4.10. Weight Percent Cesium Eluted in Test to Determine the Effect of Using Higher Cesium-Loaded Zeolite on Cesium Elution

Table 4.9. Weight Percent Iron Dissolved in Tests to Determine the Effect of Using Higher Cesium-Loaded Zeolite in Cesium Elution Tests

\begin{tabular}{cc|cc} 
sample & hours & $\begin{array}{c}\text { control } \\
\text { Test 30 }\end{array}$ & $\begin{array}{c}\text { high Cs } \\
\text { Test 39 }\end{array}$ \\
\hline T1 & 0.25 & 1.22 & 1.79 \\
T2 & 0.5 & 1.01 & 1.12 \\
T3 & 1 & 1.88 & 1.82 \\
T4 & 2 & 3.31 & 2.97 \\
T5 & 4 & 5.15 & 5.65 \\
T6 & 20 & 24.4 & 34.6 \\
T7 & 28 & 33.7 & 48.2
\end{tabular}

\subsection{Neutralization Tests}

Tests 35 and 40 were designed to evaluate how neutralizing the oxalic acid with $\mathrm{NaOH}$ affected the amount of iron and cesium in solution. This test was done to simulate quenching the actual operations in tank 8D-1 to halt corrosion of the tank by the acid. These tests differed from the control in the following ways: after the 20 -hour sample, the $\mathrm{pH}$ was recorded and $10 \mathrm{M} \mathrm{NaOH}$ was slowly added to the reaction vessel until the desired $\mathrm{pH}$ (12 in Test 35 and 5 in Test 40$)$ was reached. Samples were then drawn at 15 minutes, 30 minutes, 1 hour, 2 hours, and 4 hours after neutralization. Cesium data from these tests are shown in Table 4.10 and Figure 4.12. As Figure 4.12 shows, neutralization has little effect on the amount of cesium eluted with the cesium concentration in solution being within experimental error of the control test. The amount of cesium eluted increases slightly after the test is neutralized which may be due to an equilibrium shift in the solution; however, this shift is very small and is within experimental error. 


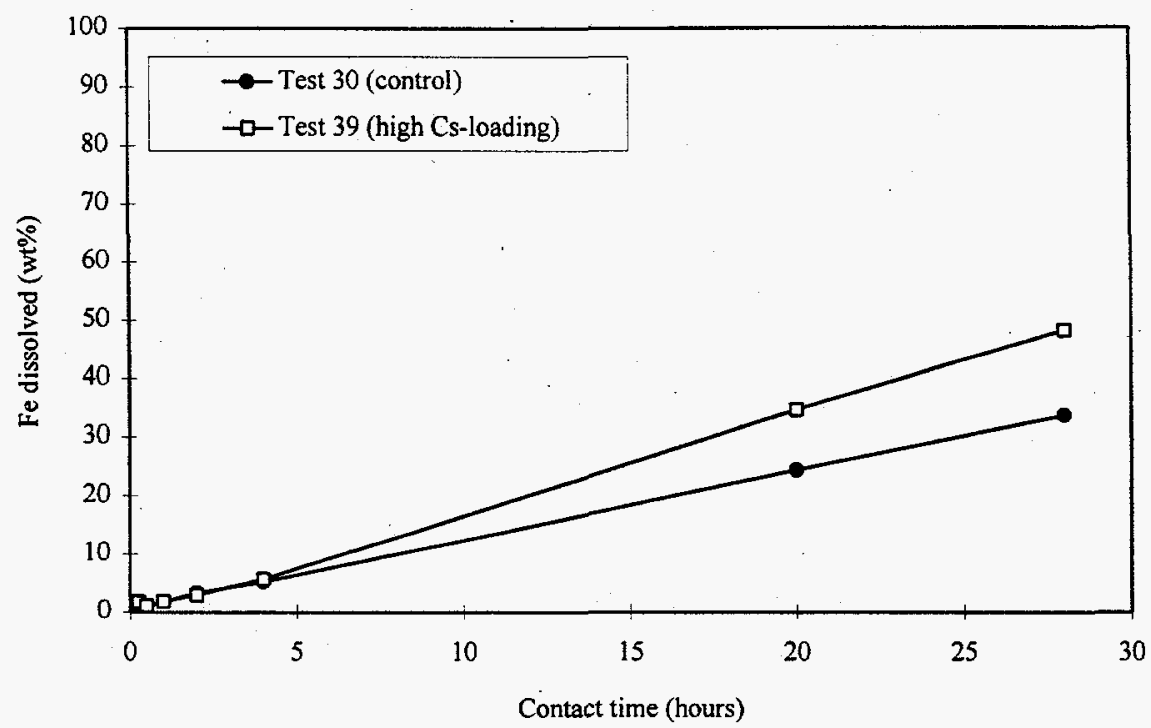

Figure 4.11. Weight Percent Iron Dissolved in Tests to Determine the Effect of Using Higher Cesium-Loaded Zeolite in Cesium Elution Tests

Table 4.10. Weight Percent Cesium Eluted in Neutralization Tests

\begin{tabular}{|c|c|c|c|c|}
\hline sample & hours & $\begin{array}{l}\text { Test } 30 \\
\text { (control) }\end{array}$ & $\begin{array}{l}\text { Test } 35 \\
\text { (neutralize } \\
\text { to } \mathrm{pH} 12 \text { ) }\end{array}$ & $\begin{array}{l}\text { Test } 40 \\
\text { (neutralize } \\
\text { to } \mathrm{pH} 5 \text { ) }\end{array}$ \\
\hline$\overline{\mathrm{T} 1}$ & 0.25 & 4.45 & 3.58 & $--^{(a)}$ \\
\hline $\mathrm{T} 2$ & 0.5 & 9.02 & 9.64 & $--^{\text {(a) }}$ \\
\hline $\mathrm{T} 3$ & 1 & 21.21 & 38.73 & $-^{(a)}$ \\
\hline $\mathrm{T} 4$ & 2 & 38.14 & 48.91 & $-{ }^{(a)}$ \\
\hline T5 & 4 & 50.88 & 65.13 & $--^{(a)}$ \\
\hline T6 & 20 & 84.66 & 80.25 & 86.86 \\
\hline N1 & 20.5 & $-^{(a)}$ & 88.97 & 92.52 \\
\hline $\mathrm{N} 2$ & 20.75 & $--^{(a)}$ & 84.70 & 93.04 \\
\hline N3 & 21.25 & -_a $^{\text {(a) }}$ & 87.72 & 92.78 \\
\hline N4 & 22.25 & -_(a) & 82.34 & 92.52 \\
\hline N5 & 24.25 & -- $^{\text {(a) }}$ & 89.44 & 94.57 \\
\hline $\mathrm{T} 7$ & 28 & 87.76 & 90.61 & $--^{(a)}$ \\
\hline
\end{tabular}

(a) Not measured. 


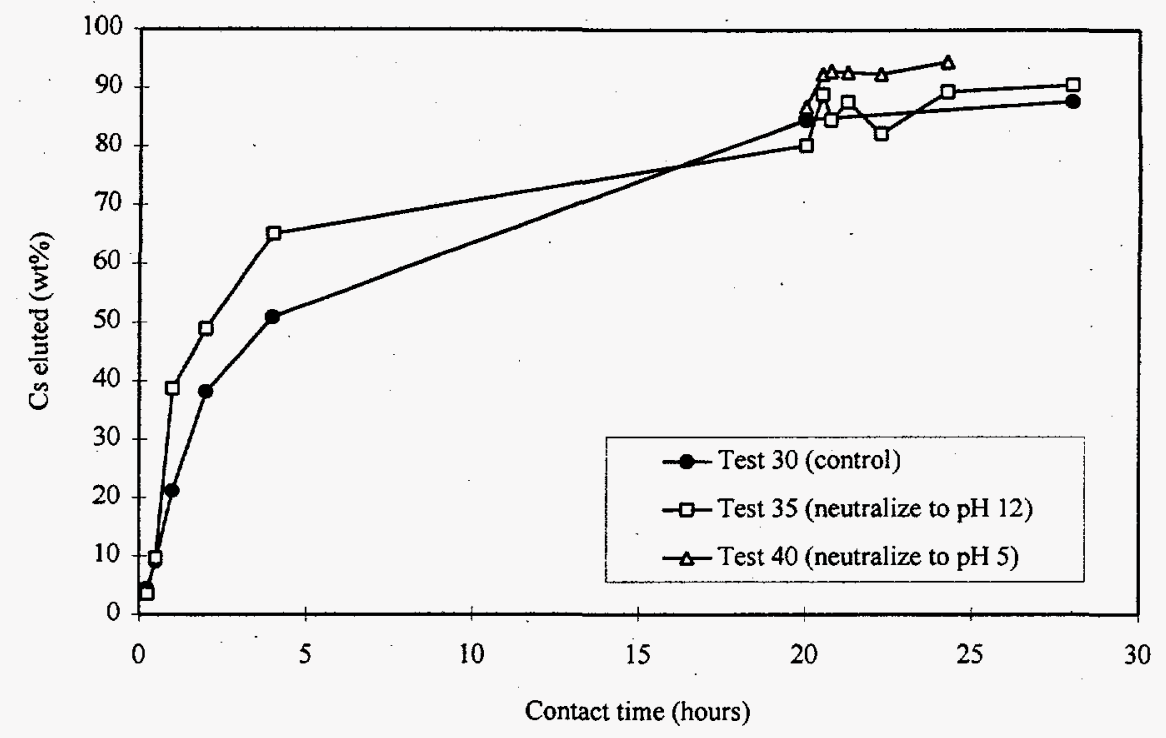

Figure 4.12. Weight Percent Cesium Eluted in Neutralization Tests

The amount of iron in solution in Tests 30,35, and 40 is shown in Table 4.11 and Figure 4.13. The figure shows that the amount of iron in solution decreases at $\mathrm{pH} 12$. However, at $\mathrm{pH} 5$, the amount of iron in solution does not seem to be affected. In the control, about $33 \mathrm{wt} \%$ of the added iron is in solution after 28 hours. In Test 40, which was neutralized to $\mathrm{pH} \mathrm{5}$, about $27 \mathrm{wt} \%$ of the iron remains four hours after neutralization, and in Test 35 , which was neutralized to $\mathrm{pH} 12$, only about $7 \mathrm{wt} \%$ of the iron remains in solution four hours later. Neutralization may decrease the amount of iron transferred to tank 8D-2 in the oxalic acid solution while having minimal impact on cesium elution.

Table 4.11. Weight Percent Iron Dissolved in Neutralization Tests

\begin{tabular}{|c|c|c|c|c|}
\hline sample & hours & $\begin{array}{l}\text { Test } 30 \\
\text { (control) }\end{array}$ & $\begin{array}{l}\text { Test } 35 \\
(\mathrm{pH} 12.5)\end{array}$ & $\begin{array}{l}\text { Test } 40 \\
\text { (pH 5) }\end{array}$ \\
\hline T1 & 0.25 & 1.22 & 3.04 & $\ldots$ (a) \\
\hline $\mathrm{T} 2$ & 0.5 & 1.01 & 2.82 & $--^{(a)}$ \\
\hline T3 & 1 & 1.88 & 3.70 & $-_{-}^{(a)}$ \\
\hline $\mathrm{T} 4$ & 2 & 3.31 & 4.35 & $--^{(a)}$ \\
\hline T5 & 4 & 5.15 & 9.25 & $--^{(a)}$ \\
\hline T6 & 20 & 24.4 & 24.40 & 27.77 \\
\hline N1 & 20.5 & $--^{a}$ & 25.23 & 26.58 \\
\hline N2 & 20.75 & $--^{a}$ & 25.69 & 27.06 \\
\hline N3 & 21.25 & $--^{a}$ & 11.09 & 27.69 \\
\hline N4 & 22.25 & $--^{a}$ & 20.12 & 26.44 \\
\hline N5 & 24.25 & $--^{a}$ & 7.33 & 27.21 \\
\hline $\mathrm{T} 7$ & 28 & 33.7 & 9.55 & $--^{(a)}$ \\
\hline
\end{tabular}

(a) Not measured. 


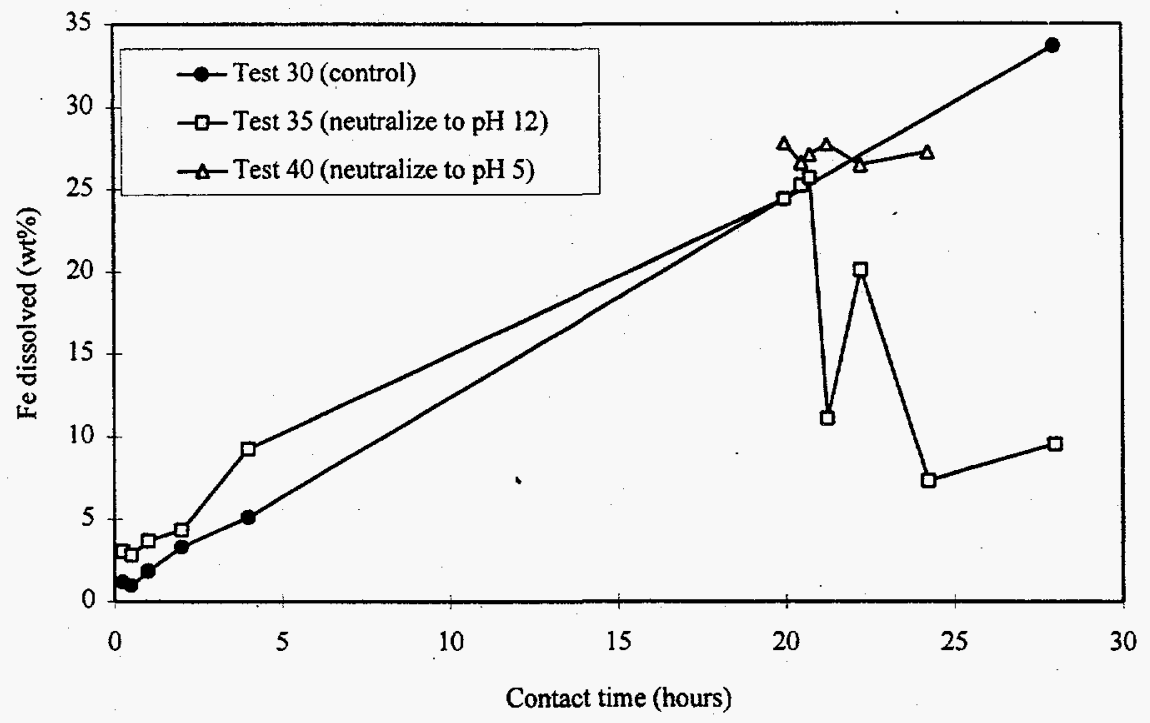

Figure 4.13. Weight Percent Iron Dissolved in Neutralization Tests

In Test $35,149.8 \mathrm{~g}$ of $10 \mathrm{M} \mathrm{NaOH}$ were required to attain a $\mathrm{pH}$ of 12.5 . The neutralization resulted in a large amount of precipitate on the bottom of the reaction vessel. The contents of the reaction vessel were filtered and dried, and $31.5 \mathrm{~g}$ of precipitate were recovered in contrast to $9.5 \mathrm{~g}$ recovered in the control. It is estimated that an additional $2-3 \mathrm{~g}$ were lost due to caking on the funnel and the bottom of the reaction vessel. X-ray diffraction analysis indicated that approximately $30 \mathrm{vol} \%$ of the precipitate was amorphous. Semi-quantitative analysis of the crystalline fraction showed $65 \mathrm{wt} \% \mathrm{Na}_{2} \mathrm{C}_{2} \mathrm{O}_{4}$ (sodium oxalate), and $35 \mathrm{wt} \% \mathrm{Fe}_{2} \mathrm{O}_{3}$ (hematite). Table 4.12 summarizes the $\mathrm{x}$-ray diffraction results for the precipitates recovered in the neutralization tests and the control.

In Test $40,48.33 \mathrm{~g}$ of $10 \mathrm{M} \mathrm{NaOH}$ were required to attain a $\mathrm{pH}$ of 5 . Neutralizing to a $\mathrm{pH}$ of 5 produced only $10.7 \mathrm{~g}$ of precipitate in contrast to $9.5 \mathrm{~g}$ for the control and $>31.5 \mathrm{~g}$ for Test 35 , in which the vessel contents were neutralized to a $\mathrm{pH}$ of 12 . The amount of material recovered in Test 40 and in the control is less than the amount of material originally added to the reaction vessel $(10 \mathrm{~g}$ zeolite and $4 \mathrm{~g}$ $\mathrm{Fe}_{2} \mathrm{O}_{3}$ ). X-ray diffraction analysis of the recovered solids indicated that approximately $45 \mathrm{vol} \%$ of the material was amorphous. Semi-quantitative analysis of the crystalline fraction showed it to contain $92 \mathrm{wt} \% \mathrm{Fe}_{2} \mathrm{O}_{3}$ (hematite).

\subsection{Relationship Between Cesium Eluted and Aluminum in Solution}

The oxalic acid solutions were also analyzed for aluminum to determine the existence of a correlation between the amount of cesium eluted and the amount of aluminum in solution. The mechanism for cesium elution is a process by which aluminum and iron within the zeolite structure dissolve, creating a larger space around the cesium atom. Aluminum is one of the principal components of zeolite IE-96 (see Table 3.1 for zeolite composition), therefore, the amount of aluminum in solution could reflect the amount of zeolite dissolved and hence the level of cesium elution. 
Table 4.12. X-Ray Diffraction Analysis of Precipitates in Neutralization Tests and Control

\begin{tabular}{l|cl} 
Test & Amorphous Content & \multicolumn{1}{c}{ Crystalline Fraction* } \\
\hline 30 (control) & 60 vol\% & 97 wt $\%$ Hematite, $\mathrm{Fe}_{2} \mathrm{O}_{3}$ \\
35 (neutralize to pH 12.5) & 30 vol\% & $\begin{array}{l}65 \mathrm{wt} \% \mathrm{Na}_{2} \mathrm{C}_{2} \mathrm{O}_{4} \\
\end{array}$ \\
& & $35 \mathrm{wt} \%$ Hematite, $\mathrm{Fe}_{2} \mathrm{O}_{3}$ \\
40 (neutralize to pH 5) & 45 vol\% & $92 \mathrm{wt} \%$ Hematite, $\mathrm{Fe}_{2} \mathrm{O}_{3}$ \\
& & $3 \mathrm{wt} \%$ Whewellite**, $\mathrm{CaC}_{2} \mathrm{O}_{4} \cdot \mathrm{H}_{2} \mathrm{O}$ \\
\hline
\end{tabular}

* semi-quantitative only

** tentative ID

Percentages of aluminum and cesium showed the same trend in each test, confirming a correlation (see Figure E.1). Figure 4.14 shows a plot of the molar ratio of aluminum to cesium in solution vs. contact time, and Figure 4.15 shows a plot of moles of aluminum vs. moles of cesium. The data for the higher cesium loading test were normalized to those of the other tests for comparison. The data plotted in these figures can be found in Appendix E. As Figure 4.14 shows, at short contact times the molar ratio of aluminum to cesium is high. However, as contact time increases, the ratio decreases quickly to a constant value. This suggests that initially several aluminum atoms must be eluted from the structure of the zeolite so that the cesium can escape. But as more and more aluminum is eluted, cesium escapes at a faster rate until a constant value is reached. Grinding placed more surface area in contact with the oxalic acid, so that both aluminum and cesium eluted at a faster rate. Therefore, the aluminum to cesium ratio for Test 36 reaches the limiting ratio more quickly. This is also shown in Figure 4.15 , where concentration of cesium increases more rapidly with increasing concentration of aluminum.

Although there seems to be a definite correlation between the amount of aluminum dissolved and the amount of cesium eluted, it is recommended that the aluminum concentration not be used as an indicator of the cesium concentration until the mechanism is completely understood. Therefore, more studies should be performed to elucidate the mechanism that controls cesium elution and aluminum dissolution. 


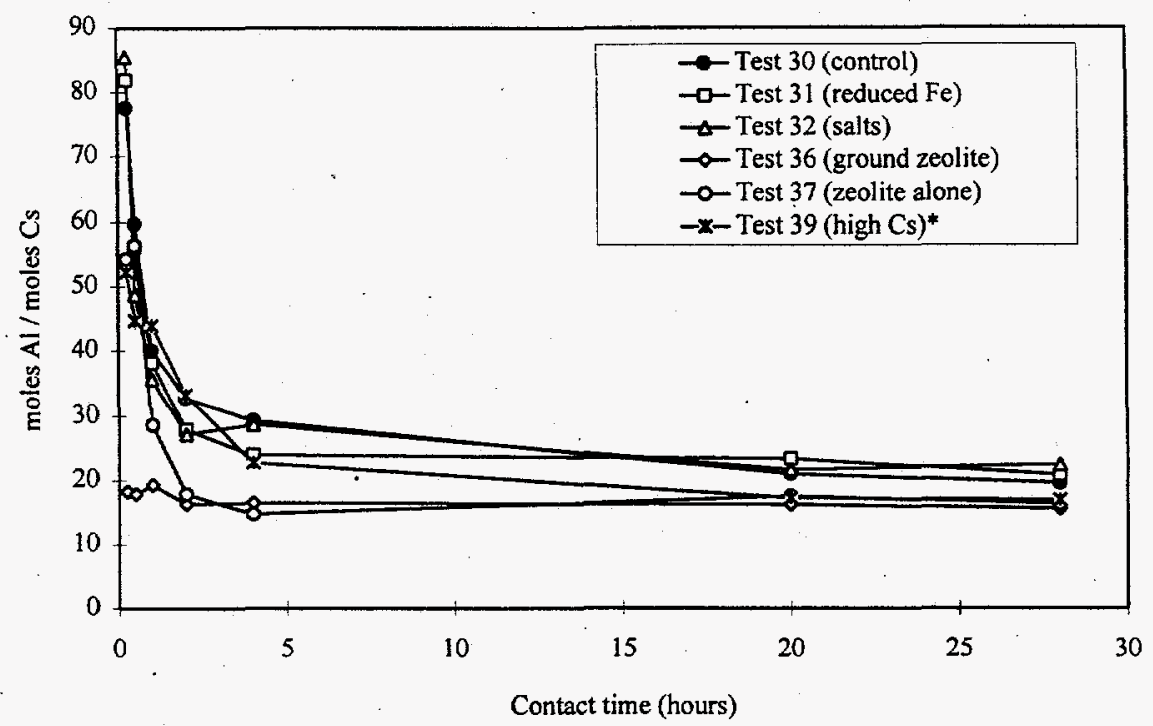

Figure 4.14. Moles of Aluminum/Moles of Cesium vs. Contact Time for Various Cesium Elution Tests

(* Normalized to control cesium loading)

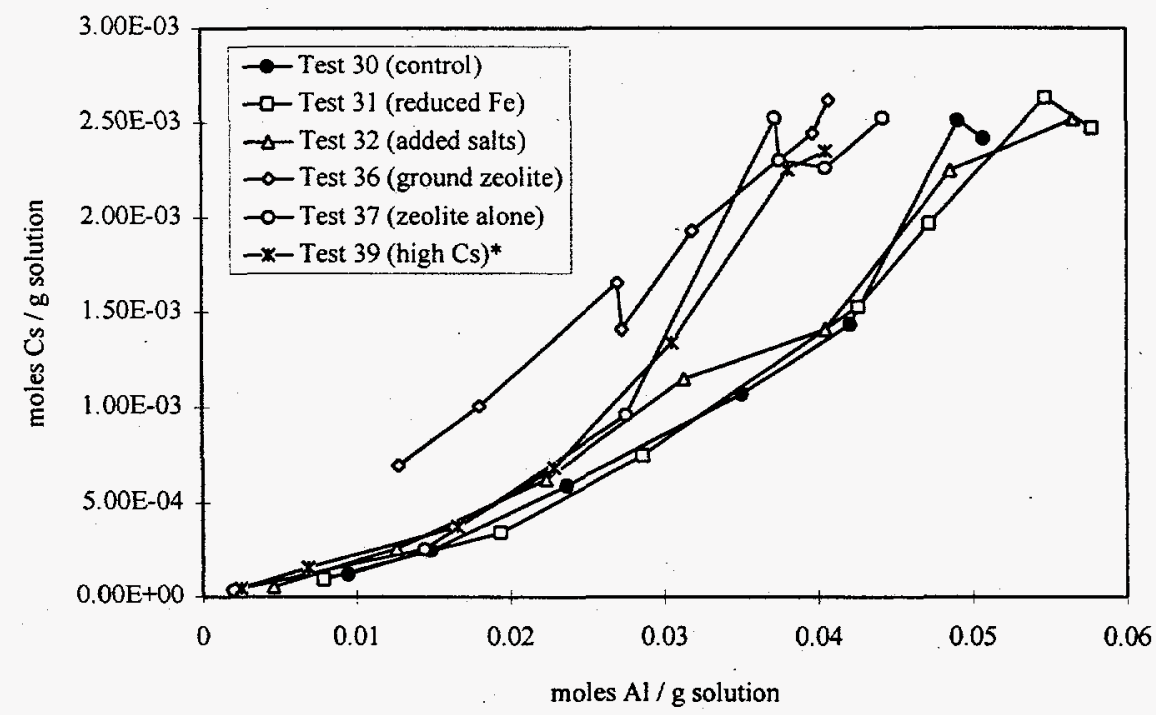

Figure 4.15. Moles of Cesium vs. Moles of Aluminum for Various Cesium Elution Tests (* Normalized to control cesium loading) 


\subsection{References}

Sills, JA, MR Elmore, GK Patello, WG Richmond, JS Roberts, RL Russell, and KD Wiemers. 1996. "Fiscal Year 1995 Laboratory Scale Studies of Cs Elution in Tank 8D-1 and Sludge

Dissolution in Tank 8D-2." PNNL-10945. Pacific Northwest National Laboratory, Richland, WA. 



\section{Appendix A}

Contact Conditions 


\section{Appendix A}

\section{Contact Conditions}

\section{Calculations for Loading Zeolite with Cesium}

Need to determine how much cesium must be loaded onto zeolite to simulate cesium loaded zeolite in tank 8D-1. The following information was provided in a fax from SC Fahey to KD Wiemers on October 7, 1994.

- total estimated pounds of zeolite in tank 8D-1 (at completion of Thorex transfer and third sludge wash) is 154,800 pounds of (this is based on $43 \mathrm{cv}$ and 3600 pounds of (dry weight) zeolite/cv)

- total estimated Curies of cesium in tank 8D-1 (at end of third sludge wash) is $5534 \mathrm{kCi}$ cesium

- $\quad 5534 \mathrm{kCi} / 154,800 \mathrm{lb}=35.75 \mathrm{Ci} / \mathrm{lb}$ zeolite

Calculations: goal is to calculate grams cesium required to give an activity level of $35.75 \mathrm{Ci} / \mathrm{lb}$ zeolite

$$
\text { Activity }=c \lambda N=c-\frac{d N}{d t}
$$

where $\mathrm{c}=$ detection coefficient, assumed to be 1 as measured $\mathrm{Ci}$ should have been normalized before it was reported

$\lambda=$ decay constant $=\ln 2 / \tau_{1 / 2}$

$\tau_{1 / 2}=$ half life

$\mathrm{N}=$ number of atoms

So need to find $\mathrm{N}$, the number of $\mathrm{Cs}$ atoms giving rise to the activity.

Assume that all of the activity is from ${ }^{137} \mathrm{Cs}(99 \%$ will be)

Assume also that this represents all of the Cs present in the tank (no ${ }^{133} \mathrm{Cs}$, etc.)

$1 \mathrm{Ci}=3.700 \times 10^{10}$ disintegrations/second (by definition)

$\tau_{1 / 2}=30.17 \mathrm{yr}$

$\lambda=\frac{\ln 2}{30.17 \mathrm{yr}}=\frac{\ln 2}{(30.17 \mathrm{yr})(365 \text { days } / \mathrm{yr})(24 \mathrm{hr} / \text { day })(3600 \mathrm{~s} / \mathrm{hr})}=7.2852 \times 10^{-10} \mathrm{~s}^{-1}$

Activity $=(35.75 \mathrm{Ci}) 3.700 \times 10^{10} \mathrm{dis} / \mathrm{s}=1.3228 \times 10^{12} \mathrm{dis} / \mathrm{s}$

$\mathrm{Ci}$ 
Then $\mathrm{N}$ can be calculated from

Activity $=c \lambda \mathrm{N}$

$1.3228 \times 10^{12} \mathrm{dis} / \mathrm{s}=(1)\left(7.2852 \times 10^{-10} \mathrm{~s}^{-1}\right)(\mathrm{N})$

$1.8157 \times 10^{21}$ atoms $=\mathrm{N}$

$$
\begin{aligned}
\mathrm{N}=1.8157 \times 10^{21} \text { atoms } \times \underset{6.0225 \times 10^{23} \text { atoms }}{1 \text { mole }} \times \frac{132.9 \mathrm{~g}}{\mathrm{~mole}} & =0.401 \mathrm{~g}{ }^{137} \mathrm{Cs} / \mathrm{lb} \text { zeolite } \\
& =0.401 \mathrm{~g} \mathrm{Cs} / 0.4525 \mathrm{~kg} \text { zeolite } \\
& =0.8862 \mathrm{~g} \mathrm{Cs} / \mathrm{kg} \text { zeolite }
\end{aligned}
$$

To load zeolite on a lab scale:

To load $1 \mathrm{~kg}$ zeolite IE-96 will require $0.8862 \mathrm{~g} \mathrm{Cs}=6.666 \times 10^{-3}$ moles $\mathrm{Cs}$

The Cs source to be used is $\mathrm{CsNO}_{3}$ (formula wt $=194.909 \mathrm{~g} / \mathrm{mole}$ )

$6.666 \times 10^{-3}$ moles $\mathrm{CsNO}_{3} \times 194.909 \mathrm{~g} / \mathrm{mole}=1.30 \mathrm{~g} \mathrm{CsNO}_{3} / \mathrm{kg}$ zeolite

When making up zeolite, remember that amounts of zeolite are based on dry weight.

Conversations with LA Bray revealed that only ${ }^{137} \mathrm{Cs}$ was figured into these calculations. Since ${ }^{137} \mathrm{Cs}$ is only $\sim 30 \%$ abundant, the cesium level in the zeolite is only about $1 / 3$ of the actual cesium content. For Test 39 , zeolite was loaded with the actual amount of cesium to determine whether elution behavior would be affected by a change in cesium loading.

If a loading of $0.886 \mathrm{~g} \mathrm{Cs} / \mathrm{kg}$ zeolite yields $30 \%$ of the amount of Cs that is in the West Valley zeolite, then the amount required for $100 \%$ loading is $0.886 / .30=2.954 \mathrm{~g} \mathrm{Cs} / \mathrm{kg}$ zeolite.

Calculations are for $25 \mathrm{~g}$ of zeolite,

$2.954 \mathrm{~g} \mathrm{Cs} / \mathrm{kg}$ zeolite $\mathrm{x} \quad 0.025 \mathrm{~kg}$ zeolite $=7.385 \times 10^{-2} \mathrm{~g} \mathrm{Cs}$

$7.385 \times 10^{-2} \mathrm{~g}$ Cs per $25 \mathrm{~g}$ zeolite

$7.385 \times 10^{-2} \mathrm{~g} \mathrm{Cs} \times \frac{1 \mathrm{~mole}}{132.9054 \mathrm{~g} \mathrm{Cs}}=5.557 \times 10^{-4}$ moles Cs

Cs will be in the form of $\mathrm{CsNO}_{3}$, with a formula weight of $194.909 \mathrm{~g} / \mathrm{mole}$

We will require $5.557 \times 10^{-4}$ moles of $\mathrm{CsNO}_{3}$ for $5.557 \times 10^{-4}$ moles Cs

$5.557 \times 10^{-4}$ moles $\times 194.909 \mathrm{~g}=0.10831 \mathrm{~g} \mathrm{CsNO}_{3}$

mole

So for $25 \mathrm{~g}$ zeolite (dry weight), will require $0.11 \mathrm{~g} \mathrm{CsNO}_{3}$ to get the correct loading. 


\section{Contact Conditions for Cs-Loading}

Table A.1. Conditions for Cesium-Loading of Zeolite

\begin{tabular}{l|ccc} 
Batch & 1 & $2 *$ & 3 \\
\hline Used for Tests & $30,31,32,35,37,40$ & 36 & 39 \\
Cs Loading, $\mu \mathrm{g} / \mathrm{g}$ & 922 & 995 & 3615 \\
Zeolite, g (dry weight) & 125 & 125 & 25 \\
Deionized Water, g & 500.1 & 500.1 & 100.1 \\
CsNO3, g & 0.1631 & 0.1631 & 0.11 \\
\hline
\end{tabular}

* this was material from batch 1 , ground and re-analyzed for Cs level

\section{Comparison of Amount of NaOH Used in FY 1995 and FY 1996}

FY 1996: used $40 \mathrm{~g}$ of $0.045 \mathrm{M} \mathrm{NaOH}$ per $10 \mathrm{~g}$ zeolite. (assume density $=1.00 \mathrm{~g} / \mathrm{mL}$ )

$(0.045 \mathrm{moles} \mathrm{NaOH} / \mathrm{L})(.04 \mathrm{~L} / 10 \mathrm{~g}$ zeolite $)(40 \mathrm{~g} \mathrm{NaOH} / \mathrm{mole} \mathrm{NaOH})=7.2 \mathrm{mg} \mathrm{NaOH} / \mathrm{g}$ zeolite FY 1995: used $2.77 \mathrm{~g}$ of $0.001 \mathrm{M} \mathrm{NaOH}$ per $5 \mathrm{~g}$ zeolite. (assume density $=1.00 \mathrm{~g} / \mathrm{mL}$ )

$(0.001 \mathrm{moles} \mathrm{NaOH} / \mathrm{L})(.00277 \mathrm{~L} / 5 \mathrm{~g}$ zeolite $)(40 \mathrm{~g} \mathrm{NaOH} / \mathrm{mole} \mathrm{NaOH})=0.02 \mathrm{mg} \mathrm{NaOH} / \mathrm{g}$ zeolite 

Appendix B

Cesium Elution Test Conditions 


.




\section{Appendix B}

\section{Cesium Elution Test Conditions}

\section{Test Conditions}

Constants:

oxalic acid concentration: $8 \mathrm{wt} \%$

oxalic acid:zeolite ratio: $40 \mathrm{~L} / \mathrm{kg}$ zeolite

amount of zeolite: $10 \mathrm{~g}$, dry weight

amount of $0.045 \mathrm{M} \mathrm{NaOH}$ (heel): $4 \mathrm{~L} / \mathrm{kg}$ zeolite

acid addition temperature: $25^{\circ} \mathrm{C}$

bath temperature: $50^{\circ} \mathrm{C}$

number of contacts: 1

time per contact: 28 hours

agitation: stir
Sampling Schedule:

15 minutes contact

30 minutes contact

1 hour contact

2 hours contact

4 hours contact

20 hours contact

28 hours contact

Table B.1. Test Matrix Used for Cs Elution Tests $30-40$

\begin{tabular}{|l|c|c|c|c|c|c|c|c|c|c|c|}
\hline Test & $\mathbf{3 0}$ & $\mathbf{3 1}$ & $\mathbf{3 2}$ & $\mathbf{3 3}$ & $\mathbf{3 4}$ & $\mathbf{3 5}$ & $\mathbf{3 6}$ & $\mathbf{3 7}$ & $\mathbf{3 8}$ & $\mathbf{3 9}$ & $\mathbf{4 0}$ \\
\hline zeolite, g & 10 & 10 & 10 & 0 & 0 & 10 & 10 & 10 & 0 & 10 & 10 \\
\hline $\mathrm{NaOH}^{*}, \mathrm{~L} / \mathrm{kg}$ & 4 & 4 & 4 & 0 & 0 & 4 & 4 & 4 & 4 & 4 & 4 \\
\hline $\mathrm{Fe}_{2} \mathrm{O}_{3}, \mathrm{~g}$ & 4 & 2 & 4 & 16 & 0 & 4 & 4 & 0 & 0 & 4 & 4 \\
\hline $\mathrm{Al}_{2} \mathrm{O}_{3}, \mathrm{~g}$ & 0 & 0 & 0 & 0 & 16 & 0 & 0 & 0 & 0 & 0 & 0 \\
\hline $\mathrm{NaNO}_{3}, \mathrm{~g}$ & 0 & 0 & 0.11 & 0 & 0 & 0 & 0 & 0 & 0 & 0 & 0 \\
\hline $\mathrm{NaNO}_{2}, \mathrm{~g}$ & 0 & 0 & 0.36 & 0 & 0 & 0 & 0 & 0 & 0 & 0 & 0 \\
\hline coupon present & & & & & & & & & $\bullet$ & & \\
\hline neutralize** & & & & & & $\bullet$ & & & & & $\bullet$ \\
\hline Analyses: & & & & & & & & & & & \\
\hline ICP-MS for Cs & $\bullet$ & $\bullet$ & $\bullet$ & $\bullet$ & $\bullet$ & $\bullet$ & $\bullet$ & $\bullet$ & $\bullet$ & $\bullet$ & $\bullet$ \\
\hline ICP-MS for Fe & $\bullet$ & $\bullet$ & $\bullet$ & $\bullet$ & $\bullet$ & $\bullet$ & $\bullet$ & $\bullet$ & $\bullet$ & $\bullet$ & $\bullet$ \\
\hline ICP-MS for Al & $\bullet$ & $\bullet$ & $\bullet$ & $\bullet$ & $\bullet$ & $\bullet$ & $\bullet$ & $\bullet$ & $\bullet$ & $\bullet$ & $\bullet$ \\
\hline XRD on zeolite & $\bullet$ & & & & & $\bullet$ & & & & & $\bullet$ \\
\hline particle size & $\bullet$ & & & & & & $\bullet$ & & & & \\
\hline
\end{tabular}

* $0.045 \mathrm{M} \mathrm{NaOH}$

** neutralization uses $10 \mathrm{M} \mathrm{NaOH}$

B. 1 

Appendix C

Temperature and pH Data for Cesium Elution Tests 



\section{Appendix C \\ Temperature and pH Data for Cesium Elution Tests}

Table C.1. Temperature and pH Data for Cs Elution Tests 30 - 34 and 36-39

\begin{tabular}{l|cc|cc|cc|cc|cc} 
& \multicolumn{3}{|c|}{ Test 30 } & Test 31 & Test 32 & Test 33 & Test 34 \\
& $\mathrm{pH}$ & $\mathrm{T}\left({ }^{\circ} \mathrm{C}\right)$ & $\mathrm{pH}$ & $\mathrm{T}\left({ }^{\circ} \mathrm{C}\right)$ & $\mathrm{pH}$ & $\mathrm{T}\left({ }^{\circ} \mathrm{C}\right)$ & $\mathrm{pH}$ & $\mathrm{T}\left({ }^{\circ} \mathrm{C}\right)$ & $\mathrm{pH}$ & $\mathrm{T}\left({ }^{\circ} \mathrm{C}\right)$ \\
\hline time 0 & 1.230 & 22 & 1.060 & 22 & 0.818 & 22 & 1.380 & 20 & 1.403 & 20 \\
15 minutes & -- & 46 & -- & 38 & - & 42 & -- & 48 & -- & 33 \\
30 minutes & -- & 53 & -- & 51 & -- & 62 & -- & 61 & -- & 52 \\
1 hour & -- & 51 & -- & 49 & -- & 57 & -- & 61 & -- & 56 \\
2 hours & -- & 50 & -- & 48 & -- & 49 & -- & 54 & -- & 51 \\
4 hours & -- & 50 & -- & 49 & -- & 51 & -- & 49 & -- & 49 \\
20 hours & -- & 51 & -- & 49 & - & 49 & - & 49 & - & 49 \\
28 hours & 0.858 & 49 & 0.818 & 49 & 0.863 & 49 & 0.760 & 49 & 0.769 & 49
\end{tabular}

\begin{tabular}{l|cc|cc||cc||cc} 
Test & Test 36 & \multicolumn{3}{|c|}{ Test 37 } & Test 38 & Test 39 \\
& $\mathrm{pH}$ & $\mathrm{T}\left({ }^{\circ} \mathrm{C}\right)$ & $\mathrm{pH}$ & $\mathrm{T}\left({ }^{\circ} \mathrm{C}\right)$ & $\mathrm{pH}$ & $\mathrm{T}\left({ }^{\circ} \mathrm{C}\right)$ & $\mathrm{pH}$ & $\mathrm{T}\left({ }^{\circ} \mathrm{C}\right)$ \\
\hline time 0 & 1.488 & 22 & 1.445 & 22 & 1.330 & 22 & 1.051 & 22 \\
15 minutes & -- & 46 & -- & 41 & -- & 53 & -- & 45 \\
30 minutes & -- & 66 & -- & 53 & -- & 56 & -- & 55 \\
1 hour & -- & 61 & -- & 53 & -- & 52 & -- & 53 \\
2 hours & -- & 49 & -- & 49 & -- & 51 & -- & 49 \\
4 hours & -- & 49 & -- & 49 & -- & 49 & -- & 49 \\
20 hours & -- & 51 & -- & 50 & -- & 51 & -- & 49 \\
28 hours & 0.732 & 48 & 0.656 & 50 & 0.627 & 53 & 0.683 & 49
\end{tabular}

Table C.2. Temperature and pH Data for Cs Elution Tests 35 and 40

\begin{tabular}{l|cc|cc} 
Test & Test 35 & Test 40 \\
& $\mathrm{pH}$ & $\mathrm{T}\left({ }^{\circ} \mathrm{C}\right)$ & $\mathrm{pH}$ & $\mathrm{T}\left({ }^{\circ} \mathrm{C}\right)$ \\
\hline time 0 & 1.042 & 20 & 0.701 & 22 \\
15 minutes & -- & 47 & -- & -- \\
30 minutes & - & 62 & -- & -- \\
1 hour & -- & 58 & -- & -- \\
2 hours & -- & 52 & -- & -- \\
4 hours & -- & 49 & -- & -- \\
neutralization (20 hours) & 0.810 & 52 & 0.684 & 51 \\
$\quad 15$ min & 12.554 & 50 & 5.366 & 53 \\
30 min & 12.653 & 48 & 5.471 & 50 \\
1 hour & 12.444 & 58 & 5.571 & 51 \\
2 hours & 12.449 & 50 & 5.681 & 51 \\
$\quad$ 4 hours & 12.383 & 53 & 5.764 & 48 \\
28 hours & 13.123 & 53 & -- & -- \\
$-=$ not measured & & & &
\end{tabular}




.




\section{Appendix D}

Sample Calculations and Formulas Used in Determination of Percent Cesium Eluted in Cesium Elution Experiments 
- 


\section{Appendix D}

\section{Sample Calculations and Formulas Used in Determination of Percent Cesium Eluted in Cesium Elution Experiments}

Table D.1. Sample Calculations and Formulas Used in Determination of Percent Cs Eluted in Cs Elution Tests $30-40$

\begin{tabular}{|c|c|c|c|}
\hline & $\mathbf{A}$ & $\mathbf{B}$ & C \\
\hline 1 & & & \\
\hline 2 & Assembly number & Test 35 & source of value \\
\hline 3 & Contact 1, time 0 : initial conditions & & \\
\hline 4 & initial amount of zeolite in reaction vessel, $\mathbf{g}$ & 10.0 & measured in laboratory \\
\hline 5 & F factor of zeolite (=dry weight/wet weight) & 1.0 & dry zeolite used; F-factor $=1$ \\
\hline 6 & amount of dry zeolite used, $\mathrm{g}$ & 10.0 & $=\mathrm{C} 4^{*} \mathrm{C} 5$ \\
\hline 7 & $\mu g$ element/g dry zeolite & 922.0 & XRF measurement \\
\hline 8 & total amount element initially present in vessel, $\mu \mathrm{g}$ & 9220.0 & $=\mathrm{C} 6^{*} \mathrm{C} 7$ \\
\hline 9 & weight of oxalic acid initially present, $\mathrm{g}$ & 407.6 & measured in laboratory \\
\hline 10 & weight of $\mathrm{NaOH}$ initially present, $\mathrm{g}$ & 40.0 & measured in laboratory \\
\hline 11 & weight of salts initially present, $g$ & 0.0 & measured in laboratory \\
\hline 12 & weight of $\mathrm{Al} 2 \mathrm{O} 3$ initially present, $\mathrm{g}$ & 0.0 & measured in laboratory \\
\hline 13 & weight of Fe2O3 initially present, $\mathrm{g}$ & 4.0 & measured in laboratory \\
\hline 14 & total initial solution weight, $\mathrm{g}$ & 447.6 & $=\mathrm{C} 9+\mathrm{C} 10$ \\
\hline 15 & weight of empty vessel, $\mathrm{g}$ & 1995.7 & measured in laboratory \\
\hline 16 & weight of loaded vessel, $\mathrm{g}$ & 2457.3 & $=\mathrm{C} 15+\mathrm{C} 6+\mathrm{SUM}(\mathrm{C} 9: \mathrm{C13})$ \\
\hline 17 & weight loss per hour, $\mathrm{g}$ & 0.0 & measured in laboratory \\
\hline 18 & Time 1 = 15 minutes & 0.25 & measured in laboratory. \\
\hline 19 & Weight of material present at $T 1, g$ & 447.6 & $=\mathrm{C} 14-\left(\mathrm{C} 18^{*} \mathrm{C} 17\right)$ \\
\hline 20 & Weight of sample removed at T1, g & 5.0 & measured in laboratory \\
\hline 21 & element concentration, run $1, \mu g$ element/g sample & 0.7 & ICP-MS measurement \\
\hline 22 & element concentration, run $2, \mu g$ element/g sample & - & not run in duplicate \\
\hline 23 & average element concentration, $\mu \mathrm{g} / \mathrm{g}$ & 0.7 & $=\mathrm{C} 21$ \\
\hline 24 & amount of element in solution at C1T1, $\mu \mathrm{g}$ & 330.3 & $=\mathrm{C} 11^{*} \mathrm{C} 23$ \\
\hline 25 & percentage element dissolved at T1 & 3.6 & $=(\mathrm{C} 24 / \mathrm{C} 8)^{*}+100$ \\
\hline 26 & Time 2 = 30 minutes & 0.5 & measured in laboratory \\
\hline 27 & Weight of material present at $T 2, g$ & 442.6 & $=\mathrm{C} 19-\mathrm{C} 20-(\mathrm{C} 26-\mathrm{C} 18)^{*} \mathrm{C} 17$ \\
\hline 28 & Weight of sample removed at T2, g & 5.1 & measured in laboratory \\
\hline 29 & element concentration, run $1, \mu g$ element/g sample & 2.0 & ICP-MS measurement \\
\hline 30 & element concentration, run 2, jg element/g sample & - & not run in duplicate \\
\hline 31 & average element concentration, $\mu \mathrm{g} / \mathrm{g}$ & 2.0 & $=\mathrm{C} 29$ \\
\hline 32 & amount of element in solution at T2, $\mu \mathrm{g}$ & 885.2 & $=\mathrm{C} 27^{\star} \mathrm{C} 31$ \\
\hline 33 & amount of element removed during $\mathrm{T1}$ sampling, $\mu \mathrm{g}$ & 3.7 & $=\mathrm{C} 20^{*} \mathrm{C} 23$ \\
\hline 34 & total amount of element dissolved at T2, $\mu \mathrm{g}$ & 888.9 & $=\mathrm{C} 32^{*} \mathrm{C} 33$ \\
\hline 35 & percentage of element dissolved at T2 & 9.6 & $=(\mathrm{C} 34 / \mathrm{C} 8)^{*} 100$ \\
\hline 36 & Time $3=1$ hour & 1.0 & measured in laboratory \\
\hline 37 & weight of material present at $\mathrm{T} 3, \mathrm{~g}$ & 437.5 & $=\mathrm{C} 27-\mathrm{C} 28-(\mathrm{C} 36-\mathrm{C} 26)^{*} \mathrm{C} 17$ \\
\hline 38 & weight of sample removed at $T 3, \mathrm{~g}$ & 5.0 & measured in laboratory \\
\hline
\end{tabular}


Table D.1 (contd)

\begin{tabular}{|c|c|c|c|}
\hline & $\mathbf{A}$ & $\mathbf{B}$ & $\mathbf{C}$ \\
\hline 39 & element concentration, run $1, \mu \mathrm{g}$ element/g sample & 8.1 & ICP-MS measurement \\
\hline 40 & element concentration, run $2, \mu \mathrm{g}$ element/g sample & -1 & not run in duplicate \\
\hline 41 & average element concentration, $\mu \mathrm{g} / \mathrm{g}$ & 8.1 & $=\mathbf{C} 39$ \\
\hline 42 & amount of element in solution at $\mathrm{T} 3, \mu \mathrm{g}$ & 3556.9 & $=\mathrm{C} 37^{*} \mathrm{C} 41$ \\
\hline 43 & amount of element removed during T1 sampling, $\mu \mathrm{g}$ & 3.7 & $=C 33$ \\
\hline 44 & amount of element removed during T2 sampling, $\mu \mathrm{g}$ & 10.2 & $=\mathrm{C} 28^{*} \mathrm{C} 31$ \\
\hline 45 & total amount of element removed during sampling, $\mu \mathrm{g}$ & 13.9 & $=$ SUM(C43:C44) \\
\hline 46 & total amount of element dissolved at $\mathrm{T} 3, \mu \mathrm{g}$ & 3570.7 & $=\mathrm{C} 42+\mathrm{C} 45$ \\
\hline 47 & percentage of element dissolved at $\mathrm{T}^{3}$ & 38.7 & $=(\mathrm{C} 46 / \mathrm{C} 8)^{*} 100$ \\
\hline 48 & Time $4=2$ hours & 2.0 & measured in laboratory \\
\hline 49 & weight of material present at $T 4, g$ & 432.5 & $=\mathrm{C} 37-\mathrm{C} 38-(\mathrm{C} 48-\mathrm{C} 36)^{*} \mathrm{C} 17$ \\
\hline 50 & weight of sample removed at $\mathrm{T} 4, \mathrm{~g}$ & 5.1 & measured in laboratory \\
\hline 51 & element concentration, run $1, \mu g$ element/g sample & 10.3 & ICP-MS measurement \\
\hline 52 & element concentration, run $2, \mu \mathrm{g}$ element/g sample & - & not run in duplicate \\
\hline 53 & average element concentration, $\mu \mathrm{g} / \mathrm{g}$ & 10.3 & $=\mathbf{C 5 1}$ \\
\hline 54 & amount of element in solution at $\mathrm{T} 4, \mu \mathrm{g}$ & 4455.0 & $=\mathrm{C} 49^{*} \mathrm{C} 53$ \\
\hline 55 & amount of element removed during T1 sampling, $\mu g$ & 3.7 & $=\mathrm{C} 33$ \\
\hline 56 & amount of element removed during T2 sampling, $\mu \mathrm{g}$ & 10.2 & $=\mathrm{C} 44$ \\
\hline 57 & amount of element removed during $T 3$ sampling, $\mu g$ & 40.5 & $=\mathrm{C} 38^{\star} \mathrm{C} 41$ \\
\hline 58 & total amount of element removed during sampling, $\mu \mathrm{g}$ & 54.4 & $=$ SUM(C55:C57) \\
\hline 59 & total amount of element dissolved at $T 4, \mu g$ & 4509.3 & $=\mathrm{C} 54+\mathrm{C} 58$ \\
\hline 60 & percentage of element dissolved at T4 & 48.9 & $=(C 59 / C 8)^{*} 100$ \\
\hline 61 & Time $5=4$ hours & 4.0 & measured in laboratory \\
\hline 62 & weight of material present at $\mathrm{T} 5, \mathrm{~g}$ & 427.4 & $=\mathrm{C} 49-\mathrm{C} 50-(\mathrm{C} 61-\mathrm{C} 48)^{*} \mathrm{C} 17$ \\
\hline 63 & weight of sample removed at $T 5, \mathrm{~g}$ & 5.1 & measured in laboratory \\
\hline 64 & element concentration, run $1, \mu \mathrm{g}$ element/g sample & 13.8 & ICP-MS measurement \\
\hline 65 & element concentration, run $2, \mu \mathrm{g}$ element/g sample & - & not run in duplicate \\
\hline 66 & average element concentration, $\mu \mathrm{g} / \mathrm{g}$ & 13.8 & $=\mathrm{C} 64$ \\
\hline 67 & amount of element in solution at $\mathrm{T5}, \mu \mathrm{g}$ & 5898.4 & $=\mathrm{C} 62^{*} \mathrm{C} 66$ \\
\hline 68 & amount of element removed during $\mathrm{T1}$ sampling, $\mu \mathrm{g}$ & 3.7 & $=\mathrm{C} 33$ \\
\hline 69 & amount of element removed during T2 sampling, $\mu \mathrm{g}$ & 10.2 & $=\mathrm{C} 44$ \\
\hline 70 & amount of element removed during T3 sampling, $\mu \mathrm{g}$ & 40.5 & $=\mathrm{C} 57$ \\
\hline 71 & amount of element removed during T4 sampling, $\mu \mathrm{g}$ & 52.5 & $=\mathrm{C} 50^{*} \mathrm{C} 53$ \\
\hline 72 & total amount of element removed during sampling, $\mu \mathrm{g}$ & 106.9 & $=S U M(C 68: C 71)$ \\
\hline 73 & total amount of element dissolved at $\mathrm{T} 5, \mu \mathrm{g}$ & 6005.3 & $=C 67+C 72$ \\
\hline 74 & percentage of element dissolved at T5 & 65.1 & $=(C 73 / C 8)^{* 100}$ \\
\hline 75 & Time $6=20$ hours & 20.0 & measured in laboratory \\
\hline 76 & weight of material present at $T 6, g$ & 422.3 & $=\mathrm{C} 62-\mathrm{C} 63-(\mathrm{C} 75-\mathrm{C} 61)^{*} \mathrm{C} 17$ \\
\hline 77 & weight of sample removed at $\mathrm{T} 6, \mathrm{~g}$ & 5.1 & measured in laboratory \\
\hline 78 & element concentration, run $1, \mu \mathrm{g}$ element $/ \mathrm{g}$ sample & 17.1 & ICP-MS measurement \\
\hline 79 & element concentration, run $2, \mu \mathrm{g}$ element/g sample & - & not run in duplicate \\
\hline 80 & average element concentration, $\mu \mathrm{g} / \mathrm{g}$ & 17.1 & $=\mathrm{C} 78$ \\
\hline 81 & amount of element in solution at $\mathrm{T} 6, \mu \mathrm{g}$ & 7221.8 & $=\mathrm{C} 76^{*} \mathrm{C} 80$ \\
\hline 82 & amount of element removed during $\mathrm{T1}$ sampling, $\mu \mathrm{g}$ & 3.7 & $=\mathrm{C} 33$ \\
\hline 83 & amount of element removed during $\mathrm{T} 2$ sampling, $\mu \mathrm{g}$ & 10.2 & $=\mathrm{C} 69$ \\
\hline 84 & amount of element removed during T3 sampling, $\mu \mathrm{g}$ & 40.5 & $=\mathrm{C} 70$ \\
\hline
\end{tabular}


Table D.1 (contd)

\begin{tabular}{|c|c|c|c|}
\hline & $\bar{A}$ & $\mathbf{B}$ & $\mathbf{C}$ \\
\hline 85 & amount of element removed during T4 sampling, $\mu \mathrm{g}$ & 52.5 & $=C 71$ \\
\hline 86 & amount of element removed during $\mathrm{T} 5$ sampling, $\mu \mathrm{g}$ & 70.2 & $=\mathrm{C} 63^{*} \mathrm{C} 66$ \\
\hline 87 & total amount of element removed during sampling, $\mu \mathrm{g}$ & 177.1 & $=$ SUM(C82:C86) \\
\hline 88 & total amount of element dissolved at $\mathrm{T} 6, \mu \mathrm{g}$ & 7399.0 & $=\mathrm{C} 81+\mathrm{C} 87$ \\
\hline 89 & percentage of element dissolved at $\mathrm{T} 6$ & 80.2 & $=(\mathrm{C} 88 / \mathrm{C} 8)^{*} 100$ \\
\hline 90 & Neutralization & & \\
\hline 91 & time to reach $\mathrm{pH} \sim 5$ & 0.25 & measured in laboratory \\
\hline 92 & weight of $\mathrm{NaOH}$ added to neutralize & 149.8 & measured in laboratory \\
\hline 93 & Neutralization time $1=15$ minutes & 20.5 & $=C 75+C 91+0.25$ \\
\hline 94 & weight of material present at N1 & 567.0 & $=\mathrm{C} 76-\mathrm{C} 77-(\mathrm{C} 93-\mathrm{C} 75)^{*} \mathrm{C} 17+\mathrm{C} 92$ \\
\hline 95 & weight of sample removed at $\mathrm{N} 1$ & 5.3 & measured in laboratory \\
\hline 96 & element concentration, run $1, \mu \mathrm{g}$ element/g sample & 14.5 & ICP-MS measurement \\
\hline 97 & element concentration, run $2, \mu \mathrm{g}$ element/g sample & 13.5 & duplicate ICP-MS measurement \\
\hline 98 & average element concentration, $\mu \mathrm{g} / \mathrm{g}$ & 14.0 & $=(\mathrm{C} 96+\mathrm{C} 97) / 2$ \\
\hline 99 & amount of element in solution at $\mathrm{N} 1, \mu \mathrm{g}$ & 7938.6 & $=\mathrm{C} 94^{*} \mathrm{C} 98$ \\
\hline 100 & amount of element removed during T1 sampling, $\mu \mathrm{g}$ & 3.7 & $=\mathrm{C} 33$ \\
\hline 101 & amount of element removed during $\mathrm{T2}$ sampling, $\mu \mathrm{g}$ & 10.2 & $=\mathrm{C} 69$ \\
\hline 102 & amount of element removed during T3 sampling, $\mu \mathrm{g}$ & 40.5 & $=\mathrm{C} 70$ \\
\hline 103 & amount of element removed during $\mathrm{T} 4$ sampling, $\mu \mathrm{g}$ & 52.5 & $=\mathrm{C} 71$ \\
\hline 104 & amount of element removed during T5 sampling, $\mu \mathrm{g}$ & 70.2 & $=\mathrm{C} 86$ \\
\hline 105 & amount of element removed during T6 sampling, $\mu g$ & 87.0 & $=\mathrm{C} 77^{*} \mathrm{C} 80$ \\
\hline 106 & total amount of element removed during sampling, $\mu g$ & 264.2 & $=\operatorname{SUM}\left(\mathrm{C}_{100: C 105)}\right.$ \\
\hline 107 & total amount of element dissolved at $\mathrm{N} 1, \mu \mathrm{g}$ & 8202.7 & $=C 99+C 106$ \\
\hline 108 & percentage of element dissolved at N1 & 89.0 & $=(C 107 / C 8)^{*} 100$ \\
\hline 109 & Neutralization time $2=30$ minutes & 20.75 & $=\mathrm{C} 93+0.25$ \\
\hline 110 & weight of material present at $\mathrm{N} 2$ & 561.7 & $=\mathrm{C} 94-\mathrm{C} 95-(\mathrm{C} 109-\mathrm{C} 93)^{*} \mathrm{C} 17$ \\
\hline 111 & weight of sample removed at N2 & 5.4 & measured in laboratory \\
\hline 112 & element concentration, run $1, \mu \mathrm{g}$ element/g sample & 13.3 & ICP-MS measurement \\
\hline 113 & element concentration, run $2, \mu \mathrm{g}$ elementg sample & $=$ & not run in duplicate \\
\hline 114 & average element concentration, $\mu \mathrm{g} / \mathrm{g}$ & 13.3 & $=\mathrm{C} 112$ \\
\hline 115 & amount of element removed during $\mathrm{T} 1-\mathrm{N} 1, \mathrm{Ng}$ & 338.9 & $=\mathrm{C} 106+\left(\mathrm{C} 95^{*} \mathrm{C} 98\right)$ \\
\hline 116 & amount of element in solution at $\mathrm{N} 2, \mu \mathrm{g}$ & 7470.6 & $=C 110^{*} \mathrm{C} 114$ \\
\hline 117 & total amount of element dissolved at N2, $\mu \mathrm{g}$ & 7809.5 & $=\mathrm{C} 115+\mathrm{C} 116$ \\
\hline 118 & percentage of element dissolved at N2 & 84.7 & $=(C 117 / C 8)^{*} 100$ \\
\hline 119 & Neutralization time $3=1$ hour & 21.25 & $=C 109+0.5$ \\
\hline 120 & weight of material present at N3 & 556.3 & $=\mathrm{C} 110-\mathrm{C} 111-(\mathrm{C} 119-\mathrm{C} 109)^{*} \mathrm{C} 17$ \\
\hline 121 & weight of sample removed at N3 & 5.4 & measured in laboratory \\
\hline 122 & element concentration, run $1, \mu \mathrm{g}$ element/g sample & 13.8 & ICP-MS measurement \\
\hline 123 & element concentration, run $2, \mu \mathrm{g}$ element/g sample & - & not run in duplicate \\
\hline 124 & average element concentration, $\mu \mathrm{g} / \mathrm{g}$ & 13.8 & $=\mathrm{C} 122$ \\
\hline 125 & amount of element removed during T1-N2, $\mu \mathrm{g}$ & 410.3 & $=\mathrm{C} 115+\left(\mathrm{C} 111^{*} \mathrm{C} 114\right)$ \\
\hline 126 & amount of element in solution at N3, $\mu \mathrm{g}$ & 7677.4 & $=\mathrm{C} 120^{*} \mathrm{C} 124$ \\
\hline 127 & total amount of element dissolved at N3, $\mu \mathrm{g}$ & 8087.7 & $=C 125+C 126$ \\
\hline 128 & percentage of element dissolved at N3 & 87.7 & $=\left(C_{127 / C 8}\right)^{*} 100$ \\
\hline 129 & Neutralization time $4=2$ hours & 22.25 & $=C 119+1$ \\
\hline
\end{tabular}


Table D.1 (contd)

\begin{tabular}{|c|c|c|c|}
\hline & $\mathbf{A}$ & $\mathbf{B}$ & $\mathbf{C}$ \\
\hline 130 & weight of material present at N4 & 551.0 & $=\mathrm{C} 120-\mathrm{C} 121-(\mathrm{C} 129-\mathrm{C} 119)^{*} \mathrm{C} 17$ \\
\hline 131 & weight of sample removed at N4 & 5.3 & measured in laboratory \\
\hline 132 & element concentration, run $1, \mu g$ element/g sample & 12.9 & ICP-MS measurement \\
\hline 133 & element concentration, run $2, \mu \mathrm{g}$ element/g sample & -1 & not run in duplicate \\
\hline 134 & average element concentration, $\mu \mathrm{g} / \mathrm{g}$ & 12.9 & $=C 132$ \\
\hline 135 & amount of element removed during $\mathrm{T} 1-\mathrm{N} 3, \mu \mathrm{g}$ & 484.5 & $=\mathrm{C} 125+\left(\mathrm{C} 121^{*} \mathrm{C} 124\right)$ \\
\hline 136 & amount of element in solution at $\mathrm{N} 4, \mu \mathrm{g}$ & 7107.4 & $=\mathrm{C} 130^{*} \mathrm{C} 134$ \\
\hline 137 & total amount of element dissolved at N4, $\mu \mathrm{g}$ & 7591.8 & $=C 135+C 136$ \\
\hline 138 & percentage of element dissolved at N4 & 82.3 & $=(C 137 / C 8) * 100$ \\
\hline 139 & Neutralization time $5=4$ hours & 24.25 & $=C 129+2$ \\
\hline 140 & weight of material present at N5 & 545.6 & $=\mathrm{C} 130-\mathrm{C} 131-(\mathrm{C} 139-\mathrm{C} 129)^{*} \mathrm{C} 17$ \\
\hline 141 & weight of sample removed at N5 & 5.3 & measured in laboratory \\
\hline 142 & element concentration, run $1, \mu \mathrm{g}$ elementg sample & 14.1 & ICP-MS measurement \\
\hline 143 & element concentration, run $2, \mu \mathrm{g}$ element/g sample & - & not measured in duplicate \\
\hline 144 & average element concentration, $\mu \mathrm{g} / \mathrm{g}$ & 14.1 & $=\mathrm{C} 142$ \\
\hline 145 & amount element removed during T1-N4, $\mu \mathrm{g}$ & 553.2 & $=\mathrm{C} 135+\left(\mathrm{C} 131^{*} \mathrm{C} 134\right)$ \\
\hline 146 & amount of element in solution at $\mathrm{N} 5, \mu \mathrm{g}$ & 7693.4 & $=C 140+C 144$ \\
\hline 147 & total amount of element dissolved at $N 5, \mu g$ & 8246.6 & $=\mathrm{C} 145+\mathrm{C} 146$ \\
\hline 148 & percentage of element dissolved at N5 & 89.4 & $=(C 147 / C 8)^{*} \times 100$ \\
\hline 149 & Time $7=28$ hours & 28.0 & measured in laboratory \\
\hline 150 & weight of material present at 77,9 & 540.3 & $=\mathrm{C} 140-\mathrm{C} 141-(\mathrm{C} 149-\mathrm{C} 139)^{*} \mathrm{C} 17$ \\
\hline 151 & weight of sample removed at $T 7, \mathrm{~g}$ & 5.3 & measured in laboratory \\
\hline 152 & element concentration, run $1, \mu g$ element/g sample & 14.3 & ICP-MS measurement \\
\hline 153 & element concentration, run $2, \mu g$ element/g sample & - & not run in duplicate \\
\hline 154 & average element concentration, $\mu \mathrm{g} / \mathrm{g}$ & 14.3 & $=C 152$ \\
\hline 155 & amount of element removed during $T 1-T 7, \mu \mathrm{g}$ & 628.2 & $=C 145+(C 141 * C 144)$ \\
\hline 156 & amount of element in solution at $T 7, \mu \mathrm{g}$ & 7726.4 & $=C 150+C 154$ \\
\hline 157 & total amount of element dissolved at $T 7, \mu g$ & 8354.7 & $=C 155+C 156$ \\
\hline 158 & percentage of element dissolved at T7 & 90.6 & $=\left(C_{157 / C 8}\right) * 100$ \\
\hline
\end{tabular}


Appendix E

\section{Data: Cesium:Aluminum}





\section{Appendix E}

\section{Data: Cesium:Aluminum}

Table E.1. Weight Percent Cesium Eluted and Aluminum Dissolved in Experiments to Determine the Effect of the Type and Amount of Iron Present on Cesium Elution

\begin{tabular}{|c|c|c|c|c|c|c|c|}
\hline \multirow[t]{2}{*}{ sample } & \multirow[t]{2}{*}{ hours } & \multicolumn{2}{|c|}{ control } & \multicolumn{2}{|c|}{$<\mathrm{Fe}$} & \multicolumn{2}{|c|}{ zeolite } \\
\hline & & $\mathrm{Al}$, Test 30 & Cs, Test 30 & $\mathrm{Al}$, Test 3 & Cs, Test 31 & $\mathrm{Al}$, Test 37 & Cs, Test 37 \\
\hline T1 & 0.25 & 19.1 & 4.45 & $\overline{15.9}$ & 3.51 & 4.15 & 1.38 \\
\hline $\mathrm{T} 2$ & 0.5 & 29.9 & 9.02 & 38.9 & 12.5 & 28.9 & 9.23 \\
\hline T3 & 1 & 47.3 & 21.2 & 57.2 & 26.9 & 54.8 & 34.4 \\
\hline T4 & 2 & 69.6 & 38.1 & 84.6 & 54.4 & 80.1 & 80.2 \\
\hline T5 & 4 & 83.1 & 50.9 & 93.4 & 69.7 & 73.8 & 89.5 \\
\hline T6 & 20 & 99.5 & 84.7 & 113 & 86.9 & 87.1 & 89.5 \\
\hline $\mathrm{T} 7$ & 28 & 96.4 & 87.8 & 107 & 92.3 & 74.4 & 81.8 \\
\hline
\end{tabular}

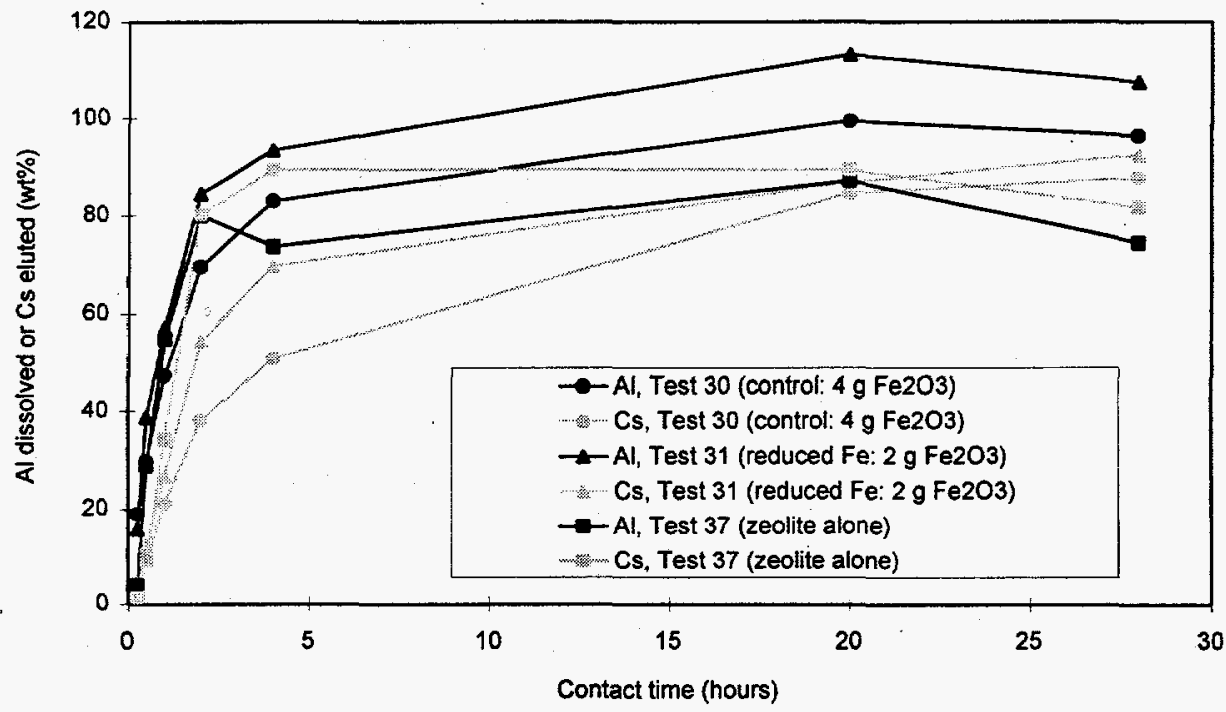

Figure E.1. Percentage of Aluminum Dissolved in Tests Containing Various Amounts of Iron 
Table E.2. Concentration of Aluminum in Solution in $\mu \mathrm{g} / \mathrm{g}$

\begin{tabular}{cc|ccc} 
sample & hours & $\begin{array}{c}\text { control } \\
\text { Test 30 }\end{array}$ & $\begin{array}{c}\text { pure } \mathrm{Al}_{2} \mathrm{O}_{3} \\
\text { Test 34 }\end{array}$ & $\begin{array}{c}\text { zeolite } \\
\text { Test 37 }\end{array}$ \\
\hline $\mathrm{T} 1$ & 0.25 & 351 & 0.563 & 76 \\
$\mathrm{~T} 2$ & 0.5 & 550 & 0.863 & 534 \\
$\mathrm{~T} 3$ & 1 & 877 & 0.125 & 1020 \\
$\mathrm{~T} 4$ & 2 & 1300 & 2.08 & 1500 \\
$\mathrm{~T} 5$ & 4 & 1560 & 2.53 & 1380 \\
$\mathrm{~T} 6$ & 20 & 1880 & 4.40 & 1640 \\
$\mathrm{~T} 7$ & 28 & 1820 & 5.28 & 1390
\end{tabular}

Note that more aluminum was dissolved in the control (Test 30), in the presence of $\mathrm{Fe}_{2} \mathrm{O}_{3}$, than in Test 37 , which contained only zeolite and no $\mathrm{Fe}_{2} \mathrm{O}_{3}$. Also note that pure $\mathrm{Al}_{2} \mathrm{O}_{3}$ does not appear to be soluble in oxalic acid, and that the phase of $\mathrm{Al}_{2} \mathrm{O}_{3}$ used in Test 34 is obviously not the same phase of $\mathrm{Al}_{2} \mathrm{O}_{3}$ in zeolite.

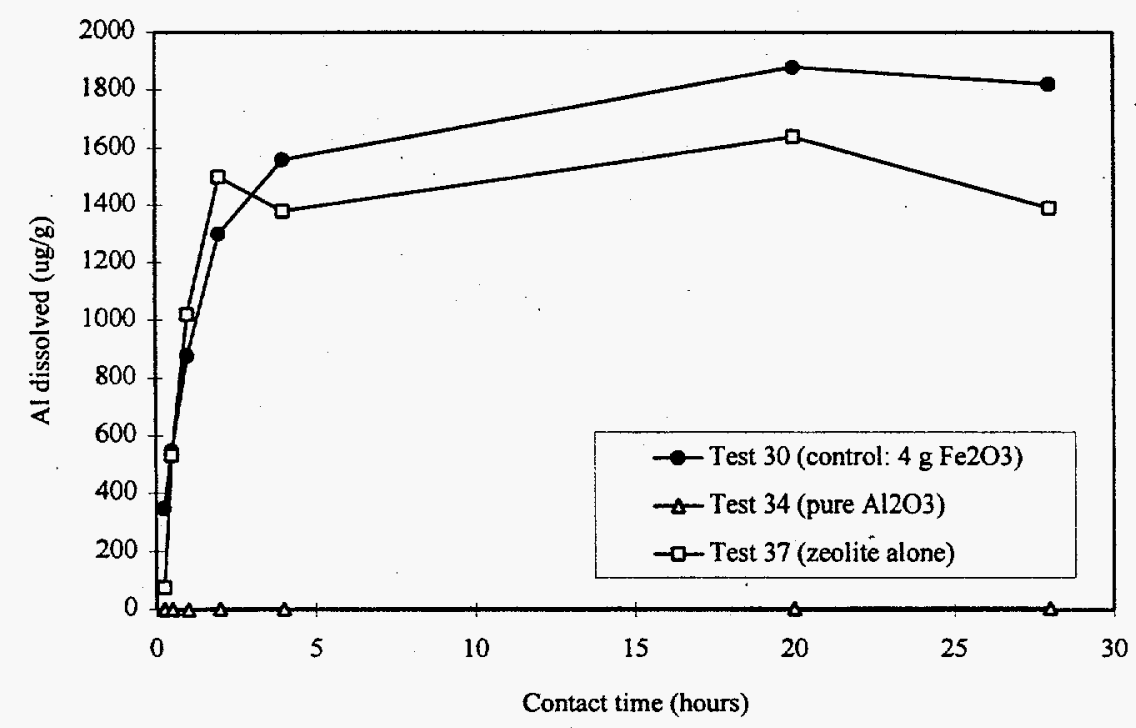

Figure E.2. Concentration of Aluminum in Solution, in $\mu \mathrm{g} / \mathrm{g}$ 
Table E.3. Weight Percent Cesium Eluted and Aluminum Dissolved in Tests to Determine Effect of Added Salts on Cesium Elution

\begin{tabular}{cc|cc|cc} 
sample & hours & \multicolumn{2}{|c|}{ control } & \multicolumn{2}{c}{ salts } \\
& & Al, Test 30 & Cs, Test 30 & Al, Test 32 Cs, Test 32 \\
\hline T1 & 0.25 & 19.1 & 4.45 & 9.33 & 1.97 \\
T2 & 0.5 & 29.9 & 9.02 & 25.3 & 9.33 \\
T3 & 1 & 47.3 & 21.2 & 44.5 & 22.4 \\
T4 & 2 & 69.6 & 38.1 & 62.1 & 40.9 \\
T5 & 4 & 83.1 & 50.9 & 79.8 & 50.0 \\
T6 & 20 & 99.5 & 84.7 & 95.0 & 78.7 \\
T7 & 28 & 96.4 & 87.8 & 110 & 87.8
\end{tabular}

The presence of added salts appears to have no effect on aluminum dissolution.

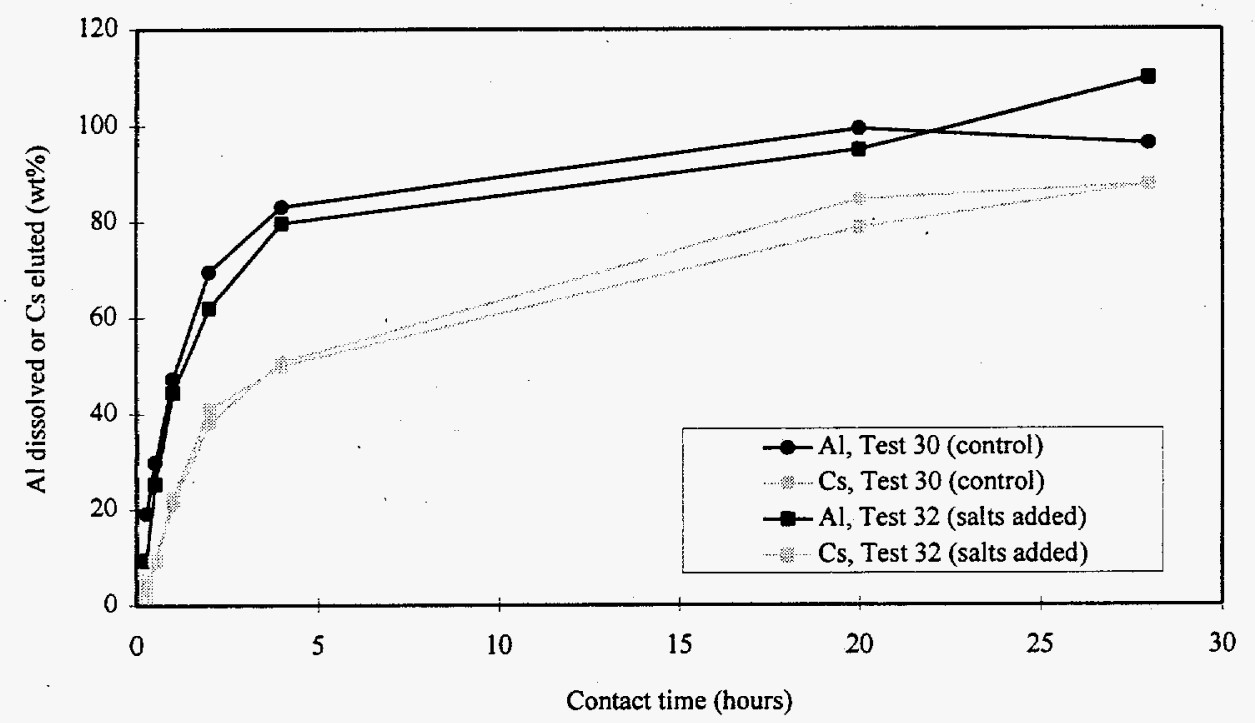

Figure E.3. Weight Percent Cesium Eluted and Aluminum Dissolved in Tests to Determine Effect of Added Salts on Cesium Elution 
Table E.4. Weight Percent Cesium Eluted and Aluminum Dissolved in Tests to Determine Effect of Reduced Particle Size Zeolite on Cesium Elution

\begin{tabular}{cc|cc|cc}
\multirow{2}{*}{ sample } & hours & \multicolumn{2}{|c|}{ control } & \multicolumn{2}{c}{ reduced particle size } \\
& & Al, Test 30 & Cs, Test 30 & Al, Test 36 Cs, Test 36 \\
\hline T1 & 0.25 & 19.1 & 4.45 & 25.8 & 23.6 \\
T2 & 0.5 & 29.9 & 9.02 & 36.3 & 34.0 \\
T3 & 1 & 47.3 & 21.2 & 54.6 & 47.3 \\
T4 & 2 & 69.6 & 38.1 & 54.1 & 55.4 \\
T5 & 4 & 83.1 & 50.9 & 63.4 & 64.2 \\
T6 & 20 & 99.5 & 84.7 & 78.3 & 80.7 \\
T7 & 28 & $96.4^{\circ}$ & $\mathbf{8 7 . 8}$ & $\mathbf{8 0 . 3}$ & 86.1
\end{tabular}

Figure E. 4 and Table E.4 show that the amount of Al dissolved in the reduced particle size test (Test 36) was less than the amount dissolved in the control (Test 30). Because of the grinding, the Al to Cs ratio is already at the constant value since the structure of the zeolite has been broken down to release the Cs more readily.

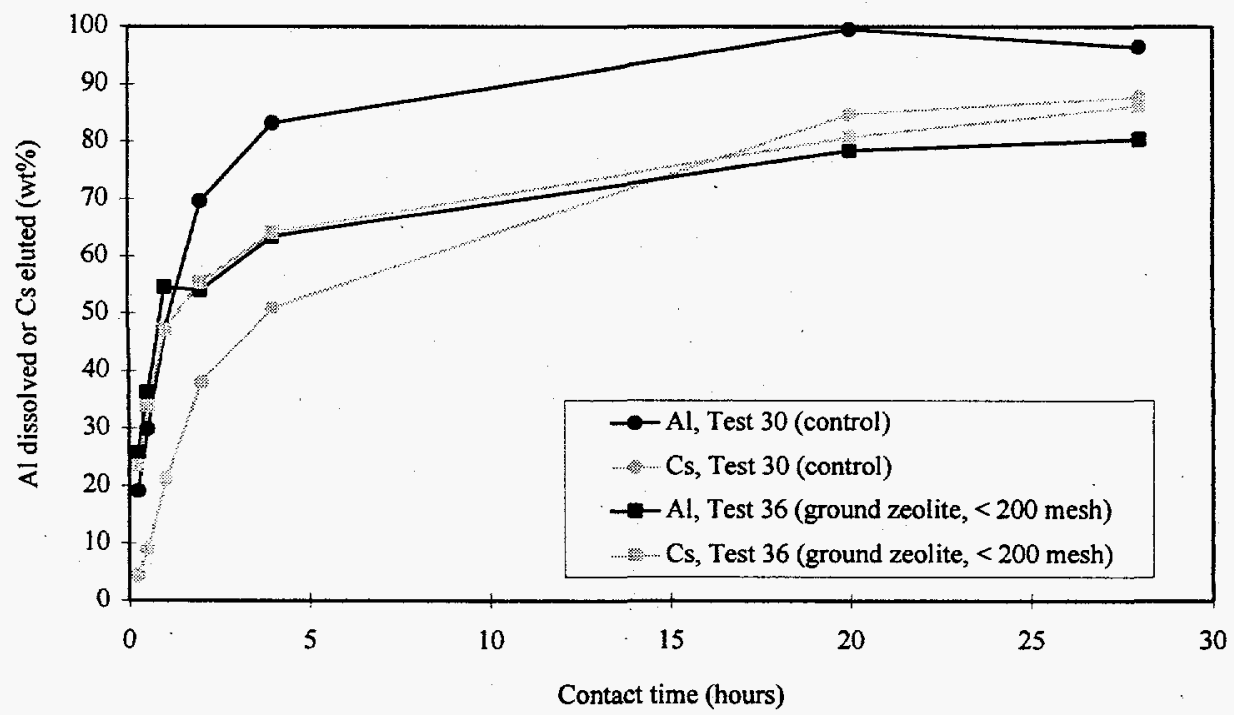

Figure E.4. Weight Percent Cesium Eluted and Aluminum Dissolved in Tests to Determine Effect of Reduced Particle Size Zeolite on Cesium Elution 
Table E.5. Weight Percent Cesium Eluted and Aluminum Dissolved in Tests to Determine Effect of Using Higher-Loaded Zeolite on Cs Elution

\begin{tabular}{cc|cc|cc} 
sample & hours & \multicolumn{2}{|c|}{ control } & \multicolumn{2}{c}{ high Cs } \\
& & Al, Test 30 & Cs, Test 30 & Al, Test 39 Cs, Test 39 \\
\hline T1 & 0.25 & 19.1 & 4.45 & 5.02 & 1.73 \\
T2 & 0.5 & 29.9 & 9.02 & 13.8 & 5.57 \\
T3 & 1 & 47.3 & 21.2 & 33.0 & 13.5 \\
T4 & 2 & 69.6 & 38.1 & 45.2 & 24.4 \\
T5 & 4 & 83.1 & 50.9 & 60.0 & 47.2 \\
T6 & 20 & 99.5 & 84.7 & 78.9 & 81.8 \\
T7 & 28 & 96.4 & 87.8 & 74.2 & 78.5
\end{tabular}

Although the amounts of Cs eluted in Tests 30 and 39 were essentially the same, the amounts of $\mathrm{Al}$ dissolved were significantly higher in the control than in the test containing higher level Cs-loaded zeolite.

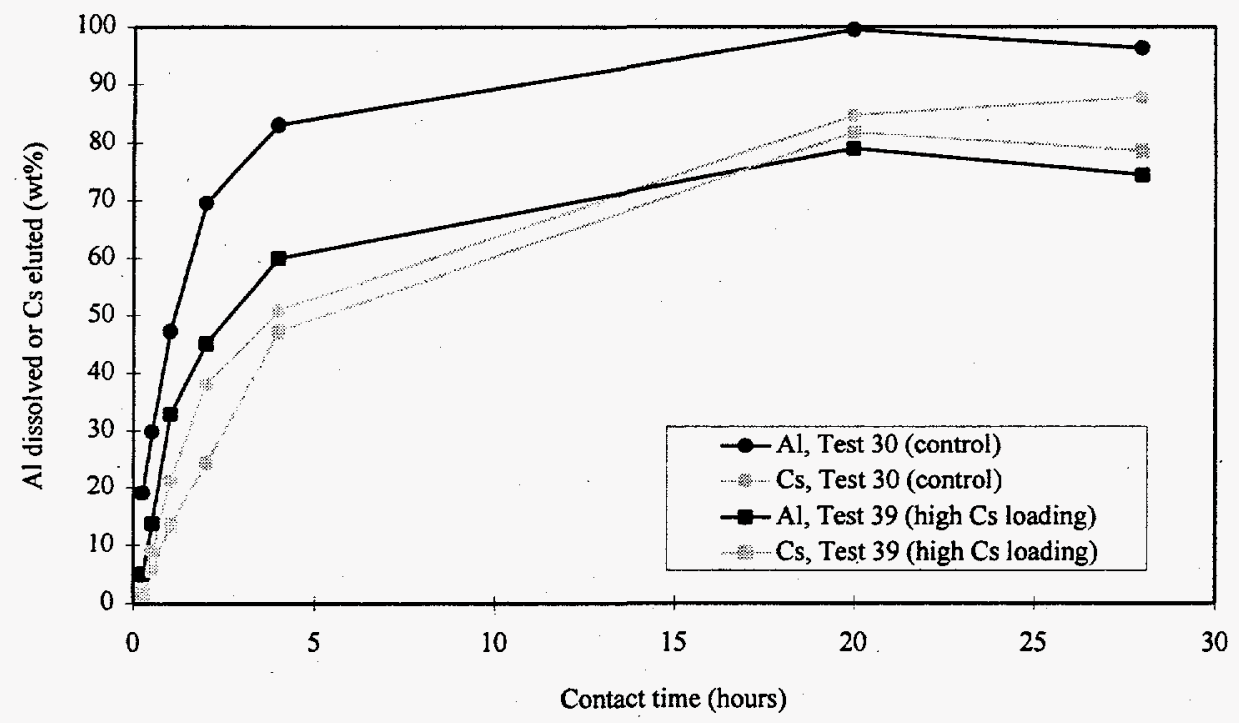

Figure E.5. Weight Percent Cesium Eluted and Aluminum Dissolved in Tests to Determine Effect of Using Higher-Loaded Zeolite on Cesium Elution 
Table E.6. Weight Percent Aluminum Dissolved in Neutralization Tests

\begin{tabular}{|c|c|c|c|c|c|c|c|}
\hline sample & hours & $\mid \begin{array}{l}\text { Al, Test } 30 \\
\text { (control) }\end{array}$ & $\begin{array}{l}\text { Cs, Test } 30 \\
\text { (control) }\end{array}$ & $\mid \begin{array}{l}\mathrm{Al}, \text { Test } 35 \\
\text { (neutralize } \\
\text { to } \mathrm{pH} 12 \text { ) }\end{array}$ & $\begin{array}{l}\text { Cs, Test } 35 \\
\text { (neutralize } \\
\text { to } \mathrm{pH} 12 \text { ) }\end{array}$ & $\mid \begin{array}{l}\mathrm{Al}, \text { Test } 40 \\
\text { (neutralize } \\
\text { to } \mathrm{pH} \text { ) }\end{array}$ & $\begin{array}{l}\text { Cs, Test } 40 \\
\text { (neutralize } \\
\text { to } \mathrm{pH} 5 \text { ) }\end{array}$ \\
\hline T1 & 0.25 & 19.12 & 4.45 & 13.09 & 3.58 & & \\
\hline $\mathrm{T} 2$ & 0.5 & 29.88 & 9.02 & 23.78 & 9.64 & & \\
\hline T3 & 1 & 47.31 & 21.21 & 49.00 & 38.73 & & \\
\hline $\mathrm{T} 4$ & 2 & $6 \dot{9.61}$ & 38.14 & 54.22 & 48.91 & & \\
\hline T5 & 4 & 83.14 & 50.88 & 67.77 & 65.13 & & \\
\hline T6 & 20 & 99.47 & 84.66 & 67.77 & 80.25 & 92.17 & 86.86 \\
\hline N1 & 20.5 & & & 83.01 & 88.97 & 87.76 & 92.52 \\
\hline N2 & 20.75 & & & 73.77 & 84.70 & 88.95 & 93.04 \\
\hline N3 & 21.25 & & & 71.05 & 87.72 & 88.95 & 92.78 \\
\hline N4 & 22.25 & & & 70.52 & 82.34 & 86.05 & 92.52 \\
\hline N5 & 24.25 & & & 53.49 & 89.44 & 85.48 & 94.57 \\
\hline $\mathrm{T} 7$ & 28 & 96.35 & 87.76 & 44.99 & 90.61 & & \\
\hline
\end{tabular}

The figure shows that, as in the case with Fe dissolution, the amount of $\mathrm{Al}$ in solution decreases with increased $\mathrm{pH}$.

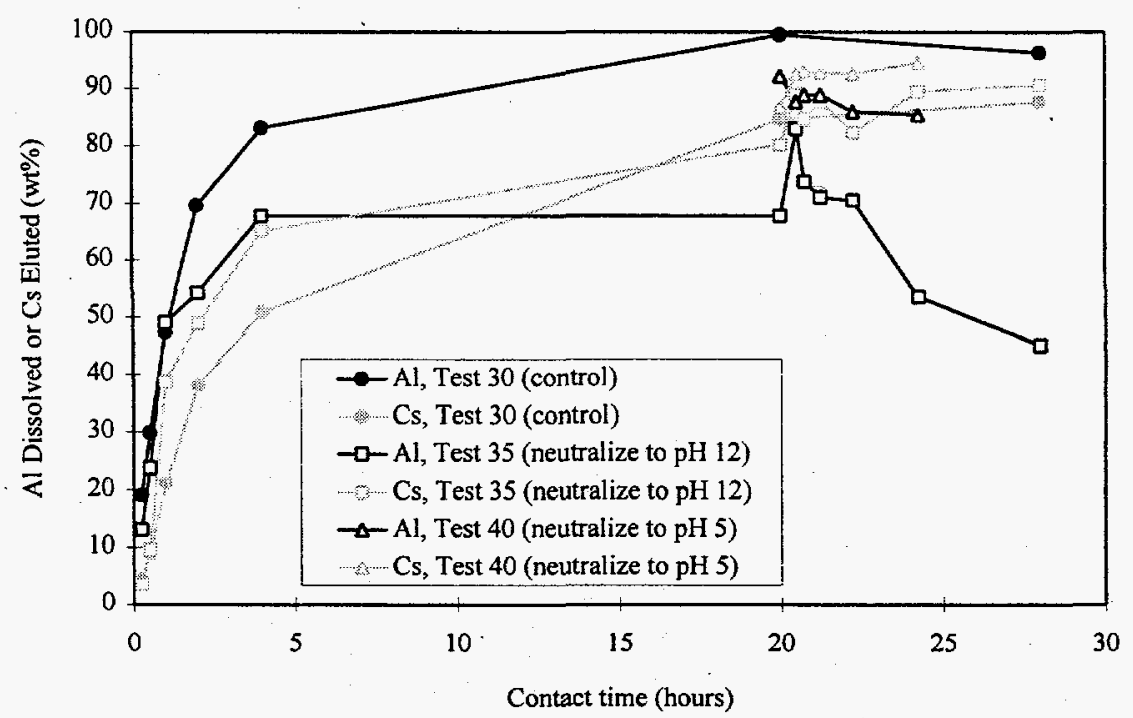

Figure E.6. Weight Percent Aluminum Dissolved and Percent Cesium Eluted in Neutralization Tests 
Table E.7(a). Test 30: Data Used in Figure 4.13, Plotting Moles Al/Moles Cs

\begin{tabular}{c|ccccc} 
& \multicolumn{5}{|c}{ Test 30: control } \\
hours & $\mathrm{Al}$ & $\mathrm{Al}$ & $\mathrm{Cs}$ & $\mathrm{Cs}$ & $\mathrm{Al} / \mathrm{Cs}$ \\
\hline 0.25 & 351 & $\mathrm{~mol} / \mathrm{g}$ & $\mu \mathrm{g} / \mathrm{g}$ & $\mathrm{mol} / \mathrm{g}$ & \\
0.5 & 550 & $1.48 \mathrm{E}-03$ & 0.917 & $1.22 \mathrm{E}-04$ & 77.60 \\
1 & 877 & $2.37 \mathrm{E}-02$ & 4.87 & $2.49 \mathrm{E}-04$ & 59.71 \\
2 & 1300 & $3.51 \mathrm{E}-02$ & 8.05 & $1.07 \mathrm{E}-04$ & 40.10 \\
4 & 1560 & $4.21 \mathrm{E}-02$ & 10.8 & $1.44 \mathrm{E}-03$ & 32.79 \\
20 & 1880 & $5.07 \mathrm{E}-02$ & 18.2 & $2.42 \mathrm{E}-03$ & 20.97 \\
28 & 1820 & $4.91 \mathrm{E}-02$ & 18.9 & $2.51 \mathrm{E}-03$ & 19.55
\end{tabular}

Table E.7(b). Test 31: Data Used in Figure 4.13, Plotting Moles Al/Moles Cs

\begin{tabular}{c|ccccc} 
& \multicolumn{5}{|c}{ Test 31: reduced Fe } \\
hours & $\mathrm{Al}$ & $\mathrm{Al}$ & $\mathrm{Cs}$ & $\mathrm{Cs}$ & $\mathrm{Al} / \mathrm{Cs}$ \\
\hline 0.25 & 292 & $\mathrm{~mol} / \mathrm{g}$ & $\mu \mathrm{g} / \mathrm{g}$ & $\mathrm{mol} / \mathrm{g}$ & \\
0.5 & 717 & $1.98 \mathrm{E}-03$ & 0.724 & $9.62 \mathrm{E}-05$ & $\mathbf{8 1 . 8 8}$ \\
1 & 1060 & $2.86 \mathrm{E}-02$ & 5.59 & $3.44 \mathrm{E}-04$ & 56.20 \\
2 & 1580 & $4.26 \mathrm{E}-02$ & 11.5 & $1.48 \mathrm{E}-04$ & 38.22 \\
4 & 1750 & $4.72 \mathrm{E}-02$ & 14.8 & $1.97 \mathrm{E}-03$ & 27.89 \\
20 & 2140 & $5.77 \mathrm{E}-02$ & 18.6 & $2.47 \mathrm{E}-03$ & 23.36 \\
28 & 2030 & $5.48 \mathrm{E}-02$ & 19.8 & $2.63 \mathrm{E}-03$ & 20.81
\end{tabular}

Table E.7(c). Test 32: Data Used in Figure 4.13, Plotting Moles A1/Moles Cs

\begin{tabular}{c|ccccc} 
& \multicolumn{5}{|c}{ Test 32: added salts } \\
hours & $\mathrm{Al}$ & $\mathrm{Al}$ & $\mathrm{Cs}$ & $\mathrm{Cs}$ & $\mathrm{Al} / \mathrm{Cs}$ \\
\hline 0.25 & 171 & $4.61 \mathrm{E}-03$ & 0.406 & $5.40 \mathrm{E}-05$ & 85.51 \\
0.5 & 467 & $1.26 \mathrm{E}-02$ & 1.94 & $2.58 \mathrm{E}-04$ & 48.87 \\
1 & 827 & $2.23 \mathrm{E}-02$ & 4.70 & $6.25 \mathrm{E}-04$ & 35.72 \\
2 & 1160 & $3.13 \mathrm{E}-02$ & 8.64 & $1.15 \mathrm{E}-03$ & 27.26 \\
4 & 1500 & $4.05 \mathrm{E}-02$ & 10.6 & $1.41 \mathrm{E}-03$ & 28.73 \\
20 & 1800 & $4.86 \mathrm{E}-02$ & 16.9 & $2.25 \mathrm{E}-03$ & 21.62 \\
28 & 2095 & $5.65 \mathrm{E}-02$ & 19.0 & $2.52 \mathrm{E}-03$ & 22.44
\end{tabular}


Table E.7(d). Test 36: Data Used in Figure 4.13, Plotting Moles Al/Moles Cs

\begin{tabular}{c|ccccc} 
& \multicolumn{5}{|c}{ Test 36: ground zeolite } \\
hours & $\mathrm{Al}$ & $\mathrm{Al}$ & $\mathrm{Cs}$ & $\mathrm{Cs}$ & $\mathrm{Al} / \mathrm{Cs}$ \\
\hline 0.25 & 472 & $1.27 \mathrm{E}-02$ & 5.24 & $6.96 \mathrm{E}-04$ & 18.29 \\
0.5 & 668 & $1.80 \mathrm{E}-02$ & 7.57 & $1.01 \mathrm{E}-03$ & 17.91 \\
1 & 1010 & $2.73 \mathrm{E}-02$ & 10.6 & $1.41 \mathrm{E}-03$ & 19.34 \\
2 & 1000 & $2.70 \mathrm{E}-02$ & 12.5 & $1.65 \mathrm{E}-03$ & 16.31 \\
4 & 1180 & $3.18 \mathrm{E}-02$ & 14.5 & $1.93 \mathrm{E}-03$ & 16.52 \\
20 & 1470 & $3.97 \mathrm{E}-02$ & 18.4 & $2.45 \mathrm{E}-03$ & 16.22 \\
28 & 1510 & $4.07 \mathrm{E}-02$ & 19.7 & $2.62 \mathrm{E}-03$ & 15.56
\end{tabular}

Table E.7(e). Test 37: Data Used in Figure 4.13, Plotting Moles Al/Moles Cs

\begin{tabular}{c|ccccc} 
& \multicolumn{5}{|c}{ Test 37: zeolite alone } \\
hours & $\mathrm{Al}$ & $\mathrm{Al}$ & $\mathrm{Cs}$ & $\mathrm{Cs}$ & $\mathrm{Al} / \mathrm{Cs}$ \\
\hline 0.25 & 76 & $2.05 \mathrm{E}-03$ & 0.284 & $3.77 \mathrm{E}-05$ & 54.33 \\
0.5 & 534 & $1.44 \mathrm{E}-02$ & 1.92 & $2.55 \mathrm{E}-04$ & 56.46 \\
1 & 1020 & $2.75 \mathrm{E}-02$ & 7.22 & $9.60 \mathrm{E}-04$ & 28.68 \\
2 & 1500 & $4.05 \mathrm{E}-02$ & 17.0 & $2.26 \mathrm{E}-03$ & 17.91 \\
4 & 1380 & $3.72 \mathrm{E}-02$ & 19.0 & $2.53 \mathrm{E}-03$ & 14.75 \\
20 & 1640 & $4.43 \mathrm{E}-02$ & 19.0 & $2.53 \mathrm{E}-03$ & 17.52 \\
28 & 1390 & $3.75 \mathrm{E}-02$ & 17.3 & $2.30 \mathrm{E}-03$ & 16.31
\end{tabular}

Table E.7(f). Test 39: Data Used in Figure 4.13, Plotting Moles A1/Moles Cs

\begin{tabular}{c|ccccc} 
& \multicolumn{5}{|c}{ Test 39: high Cs } \\
hours & $\mathrm{Al}$ & $\mathrm{Al}$ & $\mathrm{Cs}$ & $\mathrm{Cs}$ & $\mathrm{Al} / \mathrm{Cs}$ \\
\hline 0.25 & 92 & $2.48 \mathrm{E}-03$ & 1.40 & $1.86 \mathrm{E}-04$ & 13.34 \\
0.5 & 255 & $6.88 \mathrm{E}-03$ & 4.53 & $6.02 \mathrm{E}-04$ & 11.43 \\
1 & 614 & $1.66 \mathrm{E}-02$ & 11.1 & $1.48 \mathrm{E}-03$ & 11.23 \\
2 & 846 & $2.28 \mathrm{E}-02$ & 20.2 & $2.68 \mathrm{E}-03$ & 8.50 \\
4 & 1130 & $3.05 \mathrm{E}-02$ & 39.5 & $5.25 \mathrm{E}-03$ & 5.81 \\
20 & 1500 & $4.05 \mathrm{E}-02$ & 69.2 & $9.20 \mathrm{E}-03$ & 4.40 \\
28 & 1410 & $3.80 \mathrm{E}-02$ & 66.4 & $8.82 \mathrm{E}-03$ & 4.31
\end{tabular}


Table E.8. Data Used in Figure 4.14, Plotting Moles Al versus Moles Cs

\begin{tabular}{|c|c|c|c|c|c|c|}
\hline moles AI & \multicolumn{6}{|c|}{ moles Cs per g solution } \\
\hline $\begin{array}{c}\text { per g } \\
\text { solution }\end{array}$ & Test 30 & Test 31 & Test 32 & Test 36 & Test 37 & Test 39 \\
\hline $2.05 \mathrm{E}-03$ & & & & & $3.77 \mathrm{E}-05$ & \\
\hline $2.48 \mathrm{E}-03$ & & & & & & $1.86 \mathrm{E}-04$ \\
\hline $4.61 \mathrm{E}-03$ & & & $5.40 \mathrm{E}-05$ & & & \\
\hline $6.88 \mathrm{E}-03$ & & & & & & $6.02 \mathrm{E}-04$ \\
\hline $7.88 \mathrm{E}-03$ & & $9.62 \mathrm{E}-05$ & & & & \\
\hline $9.46 \mathrm{E}-03$ & $1.22 \mathrm{E}-04$ & & & & & \\
\hline $1.26 \mathrm{E}-02$ & & & $2.58 \mathrm{E}-04$ & & & \\
\hline $1.27 \mathrm{E}-02$ & & & & $6.96 \mathrm{E}-04$ & & \\
\hline $1.44 \mathrm{E}-02$ & & & & & $2.55 \mathrm{E}-04$ & \\
\hline $1.48 \mathrm{E}-02$ & $2.49 \mathrm{E}-04$ & & & & & \\
\hline $1.66 \mathrm{E}-02$ & & & & & & $1.48 \mathrm{E}-03$ \\
\hline $1.80 \mathrm{E}-02$ & & & & $1.01 \mathrm{E}-03$ & & \\
\hline $1.93 \mathrm{E}-02$ & & $3.44 \mathrm{E}-04$ & & & & \\
\hline $2.23 \mathrm{E}-02$ & & & $6.25 \mathrm{E}-04$ & & & \\
\hline $2.28 \mathrm{E}-02$ & & & & & & $2.68 \mathrm{E}-03$ \\
\hline $2.37 \mathrm{E}-02$ & $5.90 \mathrm{E}-04$ & & & & & \\
\hline $2.70 \mathrm{E}-02$ & & & & $1.65 \mathrm{E}-03$ & & \\
\hline $2.73 \mathrm{E}-02$ & & & & $1.41 \mathrm{E}-03$ & & \\
\hline $2.75 \mathrm{E}-02$ & & & & & $9.60 \mathrm{E}-04$ & \\
\hline $2.86 \mathrm{E}-02$ & & $7.48 \mathrm{E}-04$ & & & & \\
\hline $3.05 \mathrm{E}-02$ & & & & & & $5.25 \mathrm{E}-03$ \\
\hline $3.13 \mathrm{E}-02$ & & & $1.15 \mathrm{E}-03$ & & & \\
\hline $3.18 \mathrm{E}-02$ & & & & $1.93 \mathrm{E}-03$ & & \\
\hline $3.51 \mathrm{E}-02$ & $1.07 \mathrm{E}-03$ & & & & & \\
\hline $3.72 \mathrm{E}-02$ & & & & & $2.53 \mathrm{E}-03$ & \\
\hline $3.75 \mathrm{E}-02$ & & & & & $2.30 \mathrm{E}-03$ & \\
\hline $3.80 \mathrm{E}-02$ & & & & & & $8.82 \mathrm{E}-03$ \\
\hline $3.97 \mathrm{E}-02$ & & & & $2.45 \mathrm{E}-03$ & & \\
\hline $4.05 \mathrm{E}-02$ & & & $1.41 \mathrm{E}-03$ & & & \\
\hline $4.05 \mathrm{E}-02$ & & & & & $2.26 \mathrm{E}-03$ & \\
\hline $4.05 \mathrm{E}-02$ & & & & & & $9.20 \mathrm{E}-03$ \\
\hline 4.07E-02 & & & & $2.62 \mathrm{E}-03$ & & \\
\hline $4.21 \mathrm{E}-02$ & $1.44 \mathrm{E}-03$ & & & & & \\
\hline $4.26 \mathrm{E}-02$ & & $1.53 \mathrm{E}-03$ & & & & \\
\hline $4.43 \mathrm{E}-02$ & & & & & $2.53 \mathrm{E}-03$ & \\
\hline $4.72 \mathrm{E}-02$ & & $1.97 \mathrm{E}-03$ & & & & \\
\hline $4.86 \mathrm{E}-02$ & & & $2.25 \mathrm{E}-03$ & & & \\
\hline $4.91 \mathrm{E}-02$ & $2.51 \mathrm{E}-03$ & & & & & \\
\hline $5.07 \mathrm{E}-02$ & $2.42 \mathrm{E}-03$ & & & & & \\
\hline $5.48 \mathrm{E}-02$ & & $2.63 \mathrm{E}-03$ & & & & \\
\hline $5.65 \mathrm{E}-02$ & & & $2.52 \mathrm{E}-03$ & & & \\
\hline $5.77 \mathrm{E}-02$ & & $2.47 \mathrm{E}-03$ & & & & \\
\hline
\end{tabular}





\section{Distribution}

No. of

Copies

OFFSITE

2 DOE/Office of Scientific and Technical Information

6 C. S. King

West Valley Nuclear Services Co., Inc.

P.O. Box 191-10282 Rock Springs Road

West Valley, NY 141710191

\section{ONSITE}

1 U.S. Department of Energy

Richland Operations Office

R. A. Gilbert

K6-51

4 Westinghouse Hanford Company

R. A. Kirkbride

K5-27

P. S. Schaus

G3-21

G. E. Stegen

H5-27

J. A. Voogd
No. of

Copies

29 Pacific Northwest National Laboratory

L. A. Bray

P7-28

K. P. Brooks

J. L. Buelt

P7-43

M. L. Elliott

P7-41

M. R. Elmore

P7-41

J. G. H. Getting

K3-75

P7-19

L. K. Holton

K9-73

D. E. Kurath

P7-20

E. V. Morrey

P7-19

G. K. Patello (4)

P7-28

J. M. Perez

P7-41

W. G. Richmond

K6-51

R. L. Russell

P7-28

G. L. Smith

P7-41.

H. D. Smith

P7-28

J. M. Tingey

P7-25

K. D. Wiemers

K6-51

K. R. Savard

K9-04

Information Release (5)

K1-06 


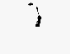

